\title{
Thoughts on the Future of Higher Education in the UK: A Personal View with a Historical Context
}

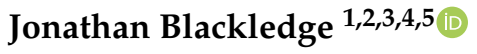 \\ 1 School of Electrical and Electronic Engineering, Technological University Dublin, D07 EWV4 Dublin, Ireland; \\ jonathan.blackledge@tudublin.ie; Tel.: +44-7584-676960 \\ 2 Department of Computer Science, University of Western Cape, Cape Town 7535, South Africa \\ 3 School of Mathematics, Statistics and Computer Science, University of KwaZulu-Natal, \\ Durban 3629, South Africa \\ 4 Faculty of Arts, Science and Technology, Wrexham Glyndŵr University of Wales, Wrexham LL11 2AW, UK \\ 5 Centre for Advanced Studies, Warsaw University of Technology, 00-661 Warsaw, Poland
}

Citation: Blackledge, J. Thoughts on the Future of Higher Education in the UK: A Personal View with a Historical Context. Educ. Sci. 2021, 11, 474. https://doi.org/10.3390/ educsci11090474

Academic Editor: Kelum A. A. Gamage

Received: 12 April 2021

Accepted: 19 August 2021

Published: 27 August 2021

Publisher's Note: MDPI stays neutral with regard to jurisdictional claims in published maps and institutional affiliations.

Copyright: (C) 2021 by the author. Licensee MDPI, Basel, Switzerland. This article is an open access article distributed under the terms and conditions of the Creative Commons Attribution (CC BY) license (https:// creativecommons.org/licenses/by/ $4.0 /)$.

\begin{abstract}
Before the effect of the COVID-19 Pandemic, there had been continued debate about the future of Higher Education (HE) in the UK. It is now accepted that the effect of the pandemic will have a long-lasting effect on HE in the UK and elsewhere. This paper addresses the changes that are currently taking place, based on a strategy that aims to develop a future knowledge-based economy, following the UK governments 2019 landmark review of HE. It explores the underlying parallels between the current situation and certain historical events that catalysed the development of a new approach to HE in the past, which is very relevant today. In this context, the paper discusses why major changes in UK HE provision is now required as a response to the fact that although the cost of education is rising, employers are reporting that graduates are increasingly unprepared for the workplace. In this respect, the paper addresses a model for HE that focuses on 'earn-asyou-learn' apprenticeships and work-place-based learning. The key to this is the emphasis that the UK government is now placing on funding new 'Technological Colleges', in which students are trained by experts from the industry on a contractual basis, rather than by university academics with tenured positions.
\end{abstract}

Keywords: Higher Education; history of education in England; apprenticeship schemes; The Triple Helix Concept; change management; technological colleges; IT in education

\section{Introduction}

Over the past few decades, the university sector has undergone a number of radical changes in which the search for an institutional competitive advantage has required new strategies to be considered [1]. However, given the economic conditions that prevail, and, in regard to the response of universities to COVID-19 [2], while the cost of Higher Education (HE) is rising, employers are reporting that graduates are increasingly unprepared for the workplace [3]. One of the underlying reasons for this is that the large majority of university staff have little or no experience in industries or the 'University of Life' that exists beyond the comfort zones of their 'Ivory Towers', leading to many universities that are not fit for purpose, e.g., [4]. Moreover, they have rarely been trained in modern teaching and training methods as is required to teach in a school, for example, and their skills base is often woefully inadequate and incompatible with industry requirements. Consequently, they are unable to move away from the rather superficial learning traditions of the past to the more in-depth training that is workplace-based oriented and employment focused. Another reason is the lack of parity of esteem that exists between vocational and university educational pathways, coupled with the poor managerial practices exercised throughout the university sector in general [5]. As a result of these issues, many governments are increasingly funding new and independent training centres that operate in close proximity 
to industies and the associated institutes and societies that support an industry, such as the Ada National College for Digital Skills, which opened its doors to students for the first time in September 2016 and was the first college of its type to be established in the UK since 1993 [6].

While universities have traditionally embraced the notion of continuous improvement for enhancing performance, it is now clear that new and fundamental changes involving radical innovations are required if the university sector is to come into parity with societal requirements. These changes will involve organisational strategies, investment, structure and operations in order to bring about a step change in the performance of universities and the value they serve. This is reflected in the UK government White Paper published in May 2016 and entitled 'Success as a Knowledge Economy: Teaching Excellence, Social Mobility and Student Choice' [7], which focuses on increasing employability and improved teaching methods to provide a boost to the UK economy. The plan is to incentivise universities to increase student employability as well as allowing more private organisations to award their own degrees. At the heart of the government proposals is a radical improvement in teaching quality through the 'Teaching Excellence and Student Outcomes Framework', which monitors and assesses different aspects of university teaching, including the student experience and the job prospects of graduates, aiming to encourage and reward universities and other educational establishments who improve their teaching standards and embed employability skills into the curriculum [8].

In regard to the issues discussed above, this work explores the future of HE in the UK in regard to the knowledge economy of the future. This is done by looking at some of the historical themes associated with HE, industry and workplace-based learning. In doing so, an attempt is made to formulate a model for Twenty-First Century HE, which is far removed from the present situation. The paper considers the principles of innovation dynamics as a driver for bringing about a step change in the organisational renewal of HE in which inter- and trans-disciplinary approaches become a natural manifestation of the notion that 'knowledge knows no boundaries' [9], unless that is, it continues to be embedded in a system that is based on what Karl Marx referred to as the 'Class Struggle' [10]. The basis for this is that education is an indispensable aid to economic and moral progress in society.

The paper embeds the 'solutions' considered in a historical context. This is done in order to reveal the similarities that have occurred in regard to education in the UK throughout its history since the first great reforms in education took place in the 1650s. Thus, the aim of this work is not to provide a narrative that is, in effect, a list of problems and solutions couched in the present (coupled with various forms of statistical information) but to 'paint' the issues of HE on a broad societal 'canvas' within a historical context. The purpose of this is to portray the similarities that exist between the present and the past, how education is related to the flux that exists between the two and the influx of new ideas that is predicated on the effects of multiculturalism. It is executed by introducing some important historical episodes that reflect the issues discussed. In this way, it is hoped that the views on education presented in this work are appreciated through a broader conceptual framework. The paper presents some ideas on how to 'stop the rot' and revitalise the UK HE sector for the sake of future generations and the UK economy, especially now that, following the Brexit on 1 January 2021, the country is a 'free agent'.

As the great English philosopher, Sir Francis Bacon once stated, "read not to contradict and confute, nor to believe and take for granted ... but to weigh and consider" [11]. In the context of this statement, the purpose of this paper is to provide some personal thoughts on education based on over thirty years of $\mathrm{HE}$ experience in the UK and overseas. In a 'nutshell', the aim of this paper is to weigh and consider the state of HE in the UK and consider the 'solutions' that are now required.

There are two principal points that should be taken into account in regard to the issues that are considered. They are as follows:

(i) University academic staff, not to mention the unions they belong to, will quite understandably vehemently disagree with the points of view discussed and the 'solutions' 
presented in this work. This is primarily because it is a direct threat to the status quo, their jobs and the comfort zones they inhabit, at least in the present. However, the ideas expressed in this work are not about the future of university academic staff, they are concerned with the future of their 'customers'.

(ii) Certain nation states who see fit to educate their children properly and are consequently experiencing considerable economic growth may find the material even more threatening than UK university staff. This is because they have come to understand that it is their interests that the UK carries on just the way that it is. It is this point that is significantly more important than that given in point (i) above.

\section{Context}

There are two specific quotes that are contextual to the themes explored in this work and express its core values. The first of these is from the 'Lord of Reason', Bertrand Russell, who said of education that: "We are faced with the paradoxical fact that education has become one of the chief obstacles to intelligence and freedom of thought" [12]. While an admirable statement, and one that probably rings true to many, especially those having to deal with the army of administrators that frequent today's universities, we must understand that this statement came from one the greatest minds of the Twentieth Century, a mind that was cultivated by the very best that any education system could offer at the time and, crucially, a mind that came from a very privileged background [13]. It is all too easy for those who have had a privileged life and achieved monumental academic success to criticise the very system that has nurtured them. On the other hand, it is the duty of those who are in such a position to do so; to point out errors in the system in order to forge solution that are for the betterment of society.

Another, which is complementary view to Russell's observations on education, is a statement from a very different source. In the 'Life of Dr Samuel Johnson' written by James Boswell in 1766, Johnson exclaims: "Talking of education, people now a-days have got a strange opinion that everything should be taught by lectures. Now, I cannot see that lectures can do so much good as reading the books from which the lectures are taken. I know nothing that can be best taught by lectures, except where experiments are to be shown. You may teach Chemistry by lectures; you might teach the making of shoes by Lectures" [14]. While one may argue that Chemistry and Cobbling are in fact very experimental and practical hands-on subjects that are not served well by lectures alone, the point that Johnson makes is well founded. It relates to the value of apprenticeships, where students learn how to actually do things and make things as opposed to being lectured to in the cloisters of a university and then being asked to sit an examination on the material that has been lectured to them. In this respect, the German-based apprenticeship scheme has been an ideal model to adopt for many years.

The strength of the German economy and its manufacturing base is well known. Consequently, Germany has the lowest youth unemployment in Europe; some 7\%, which is one of the lowest world-wide [15]. Most countries now have an increasing focus on Apprenticeships. The G20 countries, in particular, have been promoting apprenticeship programs since the financial crash of 2008 in order to enhance their manufacturing industries, a correlation that is not a coincidence. The UK had been set to establish the order of three million apprenticeships by 2020 [16], a number that has failed to be achieved to date due to a range of factors, not least Brexit and the COVID-19 Pandemic.

Apprenticeship programs are nothing new. They were pioneered in parallel to the educational systems developed in communist countries after the Second World War and underpin much of the current industrial developments in China, for example. However, one of the first state-coordinated apprenticeship programs to be put into place by a government directive was in the England. The following section discusses the historical background to this, why it occurred and the effect that it had on the future development of England and the world beyond. 


\section{On the Revolution in English Education in the Seventeenth Century}

"I beseech you, ... think it possible you may be mistaken" [17]. So said Oliver Cromwell in a letter to the general assembly of the Church of Scotland on 3 August 1650, one of England's most enigmatic and influential politicians [18]. Cromwell's statement (as given above) is arguably one of the most important of any. It applies to all aspects of the human condition, its frailty and above all, its fallibility. It is a statement that any and all scientists, philosophers and others should endeavour never to forget, irrespective of their deductive approach to experimentation and empirical data analysis and/or their induction through the powers of imagination and thought experiments. This is because it provides an intrinsic resistance to the faults that pervade human society, which is encapsulated in one of the 'Four Idols' of Sir Francis Bacon, namely, their 'Idola Specus' or 'Idol of the Cave'. This is where the problems of individuals, their passions and enthusiasms, their devotions, ideologies and theologies lead to misunderstandings in the true nature of things [19]. In regard to this particular idol, Francis Bacon could not have put it better than Oliver Cromwell: ... think it possible you may be mistaken.

Oliver Cromwell needs no introduction; his influence and legacy is well known and documented. However, given the remit of this paper, there is an aspect of his contributions to English education that, by comparison with their other exploits, is not as well appreciated as it should be. It is for this reason that his contribution to English education is now addressed. This is not done out of historical interest alone but because this history has a close synergy to current times as shall be discussed later. However, in order to understand the effect that Oliver Cromwell had on English education, it is necessary to first of all put the times in which he lived into a more general context. This is basis for the material that now follows.

One of the most important works to influence the character of education in England was the Novum Organum by Francis Bacon [20] published in 1620. This work concerns the interpretation of nature and is a critical appraisal of the so-called scientific methods of the time. As Bacon states in the Novum Organum: "Those who have taken upon themselves to lay down the law of nature as a thing already searched out and understood, have therein done philosophy and the sciences great injury". In this regard, Bacon's underlying scientific philosophy was based on the principle of induction. This was the basis upon which Galileo Galilei presented the Heliocentric model in terms of a dialogue between the two opposing ideas, i.e., the Heliocentric verses the Ptolemaic Geocentric model, the latter case being the orthodox doctrine of the time. His book entitled Dialogue Concerning Two Chief World Systems, published in 1632 [21], led to the famous trial by the inquisition in which he was forced to recant his assertion that the Heliocentric model was superior and was consequently sentenced to life long house arrest.

The trial of Galileo Galilei represents an important icon of a 'phase transition' when the scientific traditions of southern Catholic Europe moved to northern Protestant Europe, especially in England and Holland. This is not because Catholic Europeans were innately lesser scientists, intellectuals and inferior thinkers. Far from it, in general, they were better educated and literate than most and by the very authority that perceived itself to be under the threat of modernity (a very common theme in history). It is because, having observed Galileo's difficulties with the 'Roman authorities', they became fearful of openly challenging the orthodox views of the time and the 'thought policing' that accompanied it. There is an interesting irony in regard to the phase transition that was taking place in Europe at this time. Considered in retrospect, it is an icon of the times, which occurred on Christmas day, 1642. For this was the day that Galileo Galilei died; the same day that Isaac Newton was born!

At the time of Newton's birth, the Dutch were set to become a major world player in regard to sea fairing trade. This is now called the 'Dutch Golden Age' [22]. They championed immigration of those who were under the boot of their most Catholic majesties totalitarianism, given that they had had first-hand knowledge of it themselves as a result of the 'Dutch Revolt' in the mainly Calvinist Netherlandish provinces, which led to the 
outbreak of the Eighty Years' War in 1568 [23]. This included the publication of new ideas that did not fit into the Catholic ideologies and doctrines of the time. It is in this context that the last great work of Galileo, which was on mechanics (and included a summary of his early motion experiments), was published in Holland in 1638 and not in Italy, the Italian publishing houses of the time considering Galileo to be black listed. In hindsight, perhaps this was fortuitous because it was probably through Dutch engineers that Galileo's works found their way to England, and, in particular, the East Anglian region of the country, which is where Isaac Newton spent the large proportion of their early life, Cambridge University being located in this region of England.

In the first half of the 1600s, many Dutch engineers had been encouraged to relocate to East Anglia to help in the drainage of the Fenlands (the low marshy lands in the east of England) to increase the arable farming potential of the area. This started before the English civil wars under the reign of King Charles I when, in addition to other Dutch land engineers and Hydrologists, Sir Cornelius Vermuyden (1595-1683) had been appointed to introduce Dutch land-reclamation methods in England, focusing on the East Anglian region [24,25]. In this way, through the books and scientific works that were brought into England by Dutch engineers, Newton would have become aware of the works of Galileo, which were arguably the precursor to his famous work 'Principia' [26], in which the Newtonian laws of motion were first established.

In regard to the English reformation $[27,28]$, one of its major later contributors, namely Francis Bacon had died in 1626. However, their influence represented part of the phase transition that was ongoing, a transition that Galileo had prophesied, and one that we often associate with the birth of Newton. However, Newton was born into a country that was in the midst of a vicious civil war, a war that changed England and the development of science and technology more than Bacon and Newton could have ever imagined. This was due to the mindset of one of the principal characters of the English civil war [29,30], namely Oliver Cromwell (1599-1658) [31-34]. In this respect and in regard to the discussion that follows, one might associate Bacon, Newton and Cromwell as being a Holy Trinity (the father, the son and the holy ghost) of the English reformation. This is an idea that Newton himself would have reviled against, given that, as a Unitarian, he did not believe in holy trinities, conventional or otherwise-an irony, given that he was a Fellow of Trinity College, Cambridge.

After the end of the English civil wars with the parliamentarian victory at the Battle of Worcester on 3 September 1651 [35], debate continued to rage for many years on how the three kingdoms of England, Scotland and Ireland were to be governed. A so-called 'Rump' parliament had been established, which was forcibly dissolved in 1653 by Oliver Cromwell [36]. He was declared Lord Protector in December 1653, a Head of State and 'King Oliver' in all but name, a role he retained until his death five years later [18]. After his death in 1958, his son Richard assumed the title, but internal divisions among the republicans forced his resignation after just seven months. The Grandees of the New Model Army reinstalled the Rump parliament, but that too lasted less than a year, which catalysed the events leading to the restoration of the monarchy under King Charles II [37]. Nevertheless, the changes that Cromwell made in the five years he exercised full power were radical in the extreme and included a focus on the educational traditions of the time. Indeed, it may be argued that there has never been such a melting pot of radical ideas and movements in England before or since the 1650s. England was a Republic, its traditions, both political and religious, were inherently anarchic compared to the previous monarchy, and the citizens of the country were in a state of confusion. It was a period of disruptive thinking, which inspired the development of new ideas in regard to civil order, philosophy, science, theology, the nature of society and its prosperity and, above all, education.

During the Commonwealth of the 1650s, the Rump parliament and Cromwell passed many restrictive laws that sought to regulate moral behaviour. However, the most important and long-lasting effect of these times (the 1650s) is the renaissance in English education [38]. This is because control of education passed in every way from the church to 
the state. Calls for educational reform were inspired, at least in part, by a desire to improve the lot of the poor, who had suffered badly in the economic depressions of the 1630 s and faced new problems in the 1640s and 1650s, including the failure of the harvest in five consecutive years. Puritans called for a broad range of reforms, including the provision of technological and agricultural education, a system of schools to educate all children and more financial aid for deserving students. While not as widely implemented as they might have been had the Commonwealth and Oliver Cromwell lived longer, these reforms were of significant value as a means to better the status of the lower classes.

It is often perceived that the 1650s was a time of severe religious intolerance, but that is not the case. Certainly, Cromwell considered Catholicism to be not just a religion but a political force. In this respect, he was correct, but where he was significantly 'mistaken' is to consider Catholicism as being a special case. The reality of the situation was far more complex. The religious spectrum associated with England, Scotland and Ireland was very broad. Ireland remained predominantly Catholic with elegance to the previous monarchic traditions. The Anglican church continued to flourish in England, but in Scotland, the Covenanter's (catalysed by the 'Martin Luther of Scotland', namely, John Knox [39]) continued to object the influence of both the Catholic and Anglican churches.

In to this cauldron of religious reformation came the Puritans, a bias to which Cromwell belonged. However, beyond this, a number of variations on a theme began to develop in England. Some of these are now footnotes in history, but others have stood the test of time, such as the Quaker's, sometimes referred to as histories quiet revolutionaries [40] and whose origins date back to the 1650s [41]. Thus, during the 1650s, it might be argued that the Islands of Britannia and Hibernia were the scene of more short-term variations on the theme of the Protestant Reformation than had occurred in the history of Christianity since its inception by the Roman Emperor Constantine through the Edict of Milan in February 313 AD [42]. This is why there was an attempt by Charles II, during the restoration of the monarchy in the 1660s and their successors, to bring about a sense of order and religious conformity. It was undertaken by encouraging the three Kingdoms, especially England, to come back to the fold of the Anglican church.

This incurred a level of intolerance that was, in some ways, more aggressive than Cromwell's 'adventures' in Ireland, for example [43]. An icon of this period was John Bunyan [44], a Puritan non-conformist and the author of the Christian allegory The Pilgrims Progress [45], who, as a product of the 1650s, was imprisoned in Bedford jail for twelve years from 1660 to 1672 for failing to abandon their freedom of speech as a Puritan preacher. Bunyan was born into desperate poverty and illiteracy, where he would have remained had it not been for the educational reforms of the 1650s. In this sense, Bunyan was just one of a number of Englishman who had tasted the fruits of literacy and liberty and was not prepared to throw them away just because of the republic that had made them had been replaced by a monarchy that deplored him.

One of the issues that underpinned the psychology of English Puritans was that, by comparison to the Old Testament, the New Testament was perceived to be some sort of papist conspiracy. The Old Testament was taken to be a more fundamental representation of Christian values and virtue, and the Torah was perceived by the Puritan movement to be an equally valued statement on instruction, teaching and law. While the attitude of English Puritan's to Catholics and Catholicism was aggressively hostile, it was positively congenial to Jews and Judaism. Consequently, a type of spiritual brotherhood was established between the Puritans and Jews even though neither community really understood the other. It was predicated on a mutual romanticism that was devoid of any pragmatic reality but was, nevertheless, a crucial aspect of the multiculturalism that developed in those times and continues to this day.

This came at a time when England, like any other nation state that sees fit to waste its treasury on all-out war, needed to find solutions to its critical financial situation. Thus, the Commonwealth of the 1650s embarked on the development of international trade, preferably through sea fairing routes that minimised social intercourse with Europe and 
consequently needed to re-engineer its education system in order to promote trade and industry, a situation that sounds rather familiar today, i.e., Brexit. Cromwell's government, therefore, actively encouraged the emigration of well-educated and skilled foreign nationals, which included the 'readmission' of Jews into England [46-48].

Before the 1650s, England was steeped in the traditions of an educational system that was, in effect, an insular establishment and parochial cottage industry. An illustrative statement of its condition was made by Francis Bacon, when, as a witness to both their teachers and follow students at Cambridge University, he referred to them as being like becalmed ships, that never move, but by the wind of other man's breathe [49]. Moreover, the educational system was steeped in medieval Philosophy, Theology and Alchemy. Even literature, music and the arts, in general, for which England had already developed a fine and respected tradition, were exercised in terms of cultural activities based on business prospects and profitability and were not an integral part of the university experience, alcohol abuse being a necessary exception! To a personality such a Cromwell, this tradition was a red rag to a bull. Consequently, he introduced a comprehensive range of new schools, colleges and academies in which the sciences and technology took a precedence. This caused considerable offence to the academic establishment of the time and was perceived as a form of subversive criticism [38].

The perceptions of the academic establishment were quite correct. Cromwell and his government were not at all satisfied with the education system that the new republic had inherited. He wanted school leavers and university graduates to be proficient in agricultural practices, ship building, the 'art' of navigation, in the developing technologies that helped industrial outputs as well as being trained for entry into the New Model Army and Navy. He promoted and financed many of Guilds in London and beyond to help increase the number of apprenticeships. In short, Cromwell set about transforming education in England from being a parasitical museum piece to one that promoted the quest for reason, literacy, science, industry and power. In this way, although he could not have known it, he catalysed the scientific, engineering and trading dominance of England in the centuries to come. Moreover, he encouraged the emerging immigrant communities, which had been invited to flourish in the new republic, to exercise their teaching traditions for which they were, then as now, highly respected, and inculcate these traditions into their new educational model. In this context, many of the Sephardic Jews who relocated to England from Holland and from elsewhere had knowledge of the traditions exercised in Fifteenth Century Spain, which involved the translation and study of ancient Greek texts brought into Spain by Muslims as early as 711 AD. They were therefore well versed and influenced by what Francis Bacon referred to as the 'Wisdom of the Ancients' [50] (such as the great mathematical treatise Euclid's Elements [51]) and had helped to develop what Jacob Bronowski referred to as the Spanish 'blueprint' for the Italian Renaissance [52]. Thus, it was not only their teaching practices that helped the English education system to flourish but what they were teaching. Furthermore, what they were teaching was fuelling the radical changes that were taking place throughout Europe, whether through the Catholic Renaissance of southern Europe or the Protestant Reformations of northern Europe.

Coupled with the growing success of the Republic before his untimely death in 1658, and, while many of the great scientific institutions such as the Royal Society were to be established later by their monarchist successor (Charles II), Cromwell seeded what later came to be known as the Industrial Revolution. This is a revolution that could never have come about had Cromwell not introduced a vision for English education that was based on teaching excellence, which focused on the approach to science and philosophy established by characters, such as Francis Bacon, in the earlier part of that century and the introduction of fresh and well-educated blood into the country [53]. It is the reason why the Industrial Revolution is first and foremost associated with England. What is more incredible is that Cromwell's influence on history, primarily through his pragmatic policies to reforming education, was exercised in such a short period of time. This can be understood in terms of the juxtaposition of two important and relevant issues: 
(i) the search for a 'new order' and better prosperity of a population during a time of such unprecedented disruption;

(ii) the population were Islanders and thereby cut off from the short-term flow of influences from continental Europe at the time, other than through those that were readily accepted and content to contribute to Cromwell's 'New Jerusalem'.

Before the civil wars of the 1640s, England was a relatively minor player on the European theatre, with a hand-full of scholars and intellectuals that could rank with those scattered throughout renaissance Europe-Francis Bacon being one of them. However, after the civil war and well within 100 years of the event, the list of those contributing to the revolutions in science, technology and engineering that would forge the world in later centuries began to grow markedly, above and beyond the fame of scientists such as Isaac Newton. This effect can be directly attributed to Cromwell's investiture in apprenticeships, work-place-based learning and technical education. It is therefore interesting to note that, as will be discussed later, this is precisely the policy that is now being pursued by the UK government. However, it is not being driven by a radical such as Cromwell. At least, not yet!

It has been said that Oliver Cromwell was 'God's Englishman'; the 'greatest Englishman to ever walk the face of the earth' [31]. Certainly, his influence has been fundamental to the development of England since the 1650s. He was both the best and the worst of men. However, either way, he was driven by the realisation that it is not what you think or say that matters; it is only what you do that counts. In this context, what he did was drain the 'Whitehall swamp' of their time and oxygenated the pond. Furthermore, the better part of this oxygenation was the education of the land, and in their time and for that period of history, that land was England.

\section{Apprenticeships in the UK: A Historical Perspective}

The development of technical and scientific education in post-civil war England is well known, as discussed and referenced in the previous section. Those who contributed to this English scientific revolution over the centuries to come are also well known, and the products of their research form the bed-rock of science teaching throughout the world, e.g., Newtonian Mechanics, Electromagnetism, Thermodynamics and Evolutionary Biology to name but a few. It is a development that became infectious and was successively seeded into the world, starting with Scotland in the Eighteenth Century when Edinburgh became the 'Athens of the North' and where Adam Smith wrote one of the most influential books of the time, 'The Wealth of Nations' in 1776 [54]. In the latter part of the same century, France and America began to focus on science and technology to industrialise and develop a trading infrastructure, especially after their ideological and political revolutions in 1783 and 1792, respectively. In the mid-Nineteenth Century, the German speaking peoples began to contribute to the scientific revolution, and in the latter part of the same century, this was followed by Italy, Czechoslovakia, Russia and Japan, for example, who 'caught the bug'. In all cases, these transformations were necessarily accompanied by an education system that focused on the practical skills required of the work-force and nurtured the entrepreneurial talents of the people. Similarly, the industrial, manufacturing and commercial revolution that has been observed in the phenomenal China's rise to power over recent decades was, and continues to be, based on an educational infrastructure designed by the Chinese Communist Party that would be the envy of Cromwell himself.

In addition to the industrial-based democracies of western Europe, scientific education was serving its purpose in the central and eastern European states. However, there was an important difference between the two. Central and eastern European states have been, and largely continue to be, significantly more rural and predominantly agricultural-based economies. They have historically also been a refuge for academic figures persecuted elsewhere in Europe for unorthodox ideas. This reflects the focus of their educational traditions [55]. Conversely, the UK, for example, needed to maintain what it had developed and focus on the quest for trade and industry and the manufacture of products. In eastern 
Europe, there arose an 'Intelligentsia' who were free from the shackles of industrialisation and thereby had greater time to think more carefully, to educate their children more completely and, from time to time, think outside the box of industrialisation. This is why, in the latter part of the Nineteenth and early Twentieth Centuries, there developed an educational tradition that out-ranked that of the UK in subjects such as pure mathematics and theoretical physics, for example; many would argue that it still does.

It is not that the UK failed to contribute to these subjects, it did; it is that the bias towards these subjects (and many more besides) in eastern Europe was due to a lack of their industrial heritage. This provided them with the 'breathing space' to think more deeply about issues in mathematics, science and philosophy that transcended the quest of submitting patents, research grants and developing business portfolios, which has become the obsession of the Anglo-Saxon world and its capitalist quest. To this day, the issue of research in UK universities, for example, seems to have more to do with the number of short-term research grants and the overheads they attract to help fill university coffers than the quality of the intellectual work that is actually undertaken and the thought that goes into it.

Coupled with the obsession associated with the number rather than quality of the publications that are generated for the sake of various research assessment exercises, the UK university research racket appears to have failed. However, far worse than this is that the failure has come at the expense of improving and updating the curriculum of undergraduate programs, thereby depriving undergraduates of the teaching excellence they so deserve. Moreover, with dwindling state resources and significantly greater competition, the effort required to develop a research proposal with the potential to succeed in being awarded any funding often out-ranks the effort needed to conduct the research project itself.

It is arguable that the focus on encouraging the university sector to become research active and enter into the 'publications racket' was instigated by a business model introduced by Robert Maxwell and their publishing company Pergamon Press [56]. This is an example where a talented business tycoon tapped into the naivety and vanity of academics by motivating them to publishing material, often before it was worth publishing, with minimal financial return or business acumen [57]. While the Maxwell empire eventually failed in the late 1980s (a classic case of over expansion through acquisitions in the name of Thatcherism), its legacy remains and, as a result, continues to further damage the university teaching portfolio of the nation. This is exacerbated by the level of incompetence and financial mismanagement, as well as the lack of proper teacher training and appropriate and up-todate qualifications in regard to the delivery of teaching programs. Moreover, it has become coupled with an unacceptable level of student plagiarism (e.g., [58-60]), and, in some cases, plagiarism exercised by senior staff working with reputable publishers (e.g., [61]) that has become the lot of a UK university.

There is, however, a positive component to Maxwell's legacy, which is that more and more independent publishing companies have developed that focus on open-source materials and open access journals, e.g., [62]. This has afforded scholars the opportunity to publish their work without having to be constrained by the conservatism of the more conventional journals who like to maintain their elitist portfolios and have yet to fully appreciate the importance of open access publishing. Moreover, this Maxwellian development has made the need to sustain university libraries, who often continue to manipulate their rather archaic approach to controlling knowledge, an irrelevance. This is a welcome development as businesses, such as public libraries and high street shopping, for example, no longer need to be sustained at an expense to both students and learning providers alike. Thus, university libraries are being forced to transform their modus operandi and fully embrace e-access and e-learning in which knowledge knows no boundaries (physical or otherwise) and coverts minimal control [63].

The demise of education in the UK started in the mid-Nineteenth Century when the British empire was at its zenith and started to focus on consolidating is trading dominance. This involved establishing an education system that put patronage before reason, pride 
before understanding and, above all, class before social cohesion. The consequences of this were that UK education had become far removed from Cromwell's original vision and was classified into two principal categories:

(i) a 'public school system' (based on very private institutions) that focused on educating the elite for the governance of a world-wide sea fairing and trading empire;

(ii) technical institutes whose purpose was to maintain the industrial infrastructure for the 'work-shop of the world' $[64,65]$.

At the height of her imperial might and Victorian values that Britain projected throughout the world, the entire edifice was to be challenged quite unexpectedly. The effect of this was to change the emphasis of its educational infrastructure by, once again, turning to Cromwellian values, as shall now be discussed.

In the 1870s, starting in 1873, a 'Great Depression' occurred world-wide, which was particularly severe in the UK [66]. There were a number of prior events that generated not only severe economic circumstances for the UK but prompted a reappraisal of its industrial heritage. The first of these was related to the American Civil War, 1861-1865 [67]. Although the UK remained officially neutral, it indirectly supported the Southern States or Confederacy - the Confederate States of America (CSA). This was because of the UK's reliance on Cotton imports from the CSA, which sourced the textiles industries in the north of England, a highly lucrative trade due primarily to the slave economy of the southern states, which kept the price of cotton to a minimum.

As the American civil war developed, the UK looked elsewhere for its Cotton, which included developing what became a primary source in Egypt. However, as a result of the Union victory, the price of Cotton and other imports from the new world grew rapidly. However, more importantly for the UK, the American civil war catalysed an industrial revolution forged in the manufacture of arms that, by the 1870 's, had begun to show its competitive advantage over the UK's ageing industrial infrastructure, which was a relatively uncoordinated complex of cottage industries dating back to the Industrial Revolution of the Eighteenth Century.

Another emerging industrial competitor of the UK at the same time, and one that was even more uncomfortable due to its close proximity to the 'home fires', was the newly formed state of Germany, which was officially proclaimed on 18 January, 1871, under the leadership of Otto von Bismarck, who was the first Chancellor of the new state until 1890 [68]. In both the USA and Germany, there were major initiatives to promote science, engineering and technology in order to support the growth of these new nation states and develop their future prosperity. In the USA, this was driven by private enterprises and entrepreneurship, the icons of which included, Thomas Edison and Alexander Bell, for example. In Germany, central government was more pro-active in launching industrialisation, which was primarily centred, then as now, in the North Rhine Westphalia and Lower Saxony regions of the country that had ample natural resources-most notably, Coal and Iron Ore (similar to the industrial north of England, involving major industrial centres compounded in cities such a Manchester, Sheffield and Newcastle, for example). This disturbed the status quo of the British establishment for similar reasons to those associated with the current emergence of China today, which is disturbing the balance of an assumed normality of a world dominated by the USA.

In order to help tame the emerging 'German Tiger' and indirectly control it, the British government covertly helped to oust Bismarck and their republican sympathies and place the control of Germany in the hands of Emperor Wilhelm II [69]. By comparison with Bismarck, a Prussian aristocrat, a graduate of law from Göttingen University and the political genius of their time, the only qualification for the position that Kaiser Wilhelm II had was being the eldest grandson of Queen Victoria. He was a psychological wreck and unfit to hold any executive office, let alone the office of head of state. However, that was not the point. The point was that he was considered by the British establishment to be a member of the 'Club' (of unelected heads of state). Thus, it may be argued that, in trying to control Germany through introducing a reflection of themselves, the British inadvertently 
did much to catalyse the European Civil wars between 1912 and 1989 . This led to the untimely death of tens of millions of people who, had they lived, might have contributed so much to society, which might perhaps be a better part of the curriculum in our schools and universities today.

Under the leadership of Bismarck, Germany flourished in the arts and sciences and was set to becoming a major industrial and economic power, served by a progressive written constitution, a state education system with a broad curriculum and a social welfare provision that was decades ahead of the UK for the time. Bismarck was in fact the first to establish a welfare state in a modern industrial society with the social welfare legislation of 1883 [70]. The UK only developed a societal infrastructure of a similar standing in the late 1940s with the provisions of the Beveridge Report in 1942, leading to such reforms as the National Health Service, child benefit and state education [71] under the Attlee ministry, 1945-1951. However, there was one important thing that the UK did do in response to Bismarck's initiatives, which were putting the industrial infrastructure of the UK to shame. This was the development of new educational centres for technical training, the most iconic of which was the centre established in South Kensington, London, namely the Central Institute of the City and Guilds of London. This institute is now known as Imperial College (IC), which is one of the premier scientific, technical and research establishment in the world, considered to be the Massachusetts Institute of Technology (MIT) of the UK.

MIT has an unparalleled pedigree, which is well known and needs no introduction. It's motto is: mens et manus, meaning 'mind and hand' and is concerned with the 'pursuit of practical knowledge' [72]. In other words, MIT's primary purpose is teaching and research with relevance to practical issues and, in doing so, transforming society for the better; something that Oliver Cromwell would have no doubt, whole-heartedly approved of. This is because the outputs of establishments, such as MIT, along with the California Institute of Technology, Imperial College and many other institutes of science and technology have done more to change society for the better than the cumulative sum of most other HE establishments in the UK and world-wide.

Imperial College has an interesting history in that after developing its technical training services as a City and Guilds centre, it joined London University in 1908, only to leave the university in October 2006. This occurred under the leadership of the Rector and former chairman of GlaxoSmithKline, Sir Richard Sykes, who stated that: Imperial has an international reputation that is independent of the University of London. It is absolutely right that we should promote our own identity and award our own degrees [73]. Imperial College was the last college to join London University in 1908 and the first to leave it in 2006. One of the underlying reasons for this was that IC wanted to 'go back to its City and Guilds roots' [74], a model that the majority of UK universities will now have to follow. This is not the first time that the IC model has been acknowledged as a good template. In the 1960s, under the Labour government, Prime Minister Harold Wilson introduced the 'White Heat of Technology' as being the key to forging a progressive socialist society [75]. The City and Guilds heritage associated with IC was seen as being made of the right stuff (as it is today by the current government). Consequently, IC benefited from increased subsidies at the expense of many other colleges that constituted London University and, subsequently, 'went to the wall' in the rationalisation of the university undertaken in the 1980s.

The introduction of a 'mens et manus' policy will not be achievable within the current framework of British society, given the nature of those who occupy much of the academic establishment-those who rarely have any experience within industries and the 'University of Life'. The solution, therefore, requires a significantly more radical strategy. One of the better and more culturally compatible models for this strategy is ironically the same as that which created Imperial College, i.e., the German model developed under the chancellorship of Otto von Bismarck. In Germany today, over 50\% of school leavers go straight into the industry and not into a university. This is partly because of the traditional apprenticeship system, which allows young Germans who do not go to university to train and qualify in companies [15]. By comparison, in the UK, while the cost of education is rising, employers are continually 
noticing that graduates are increasingly unprepared for the workplace compared to their German counterparts and are further burdened with debt. This observation warrants an obvious question, namely how can UK graduates be prepared for the workplace if they are being educated by those who have no experience in that workplace?

More and more of the primarily G20 countries now have an increasing focus on apprenticeships, and the British government stated that some three million apprenticeships should be created by 2020. This is a figure that has not been realised, and yet, the UK is luckier than most in that it has an established institution, the City and Guilds London Institute, with a wealth of experience dating back to 1881 when the British government woke up to the emerging competition in the technological prowess of Germany and the USA. Compared to Germany, there are of course less manufacturing industries in which to place school leavers since the UK has transformed into a service-based economy over the past forty years. A more subtle but equally, if not more powerful reason, is the psychology and perceptions of those that are a product of the eternal class struggle that continues to pervade British society, one which was finally and utterly destroyed for the better in Germany in 1945.

The background to this problem is perhaps well expressed in Philip Larkin's poem This Be The Verse [76]. For too many years, depending upon the aspirations, cultural context and class bias of the populous, parents have quite understandably sought to give their children advice in regard to their futures, including the character of their education and, critically, the subject areas in which they appear to have an interest. However, this has been and continues to be done under a fog of ignorance and prejudice. In the past (i.e., 1960-1990s), middle class students were expected to undertake a university degree in a range of often very superficial and non-technical subjects in order to mature into a career that was independent of the subject matter that had been studied. They represented a small minority of UK students that had the opportunity to graduate from HE sectors that were fully supported by the British tax payer. Working class students were typically expected to undertake training in the old Polytechnic sector or enter into the manufacturing industries available, where they had the opportunity to obtain a City and Guilds qualification, for example, as part of their apprenticeship.

The demarcation between the university elite and the polytechnic proletariat at the time was challenged by the Labour government of the mid-1960s through the establishment of the Open University (OU), which was granted university status on 23 April 1969. This was the brain child of Prime Minister Harold Wilson, who was a strong advocate of providing university education to a wider class of students and referred to it as the 'Peoples University' [77]. The OU model is now well established worldwide. However, what is more interesting is the increasing number of National Vocational Qualifications (NVQs) [78] that the OU and other universities now offer, some of them being very reputable 'Russell Group' institutes [79]. In other words, they are offering the very type of vocational City and Guilds qualifications that the $\mathrm{OU}$ was originally designed to help the working classes escape from and aspire to greater heights. In this regard, we are witnessing a reversal of fortunes in terms of the debt and contempt that a degree now represents and the value and respect that a NVQ is developing, especially when it is gained through an 'earn-as-you-learn' scheme through which school leavers enter the 'University of Life' [80]. It is within this context and the economic realities associated with the evolving realpolitik that schools and parents must start to advise the younger generations, lest they continue to be suckered into a university education that has passed its sell-by date. Furthermore, to the rescue should come the apprenticeship schemes and the new Technological Colleges with a largesse that is predicated on learning modes of education that work in league with industry for industry. This 'Triple Helix Model' [81], as it has come to be known, is discussed in the following section. 


\section{The Triple Helix Model, Leo Szilard and the Information Technology Revolution}

The Triple Helix Model (THM) is one that considers the interaction between university, industry and government to be the key to innovation and growth in a knowledge-based economy. Although the phrase 'Triple Helix Model' is original, the concept is not. Moreover, while the concept continues to be debated by the executives in many UK universities, the underlying reality is that the majority of academics are not fit for purpose in regard to understanding the THM let alone endorsing it. However, they could be, if and only if they could learn to respect it rather than fear it and, because of their fear, hold it in contempt. Thus, rather than re-iterating aspects of the THM that are well known and can be better explored elsewhere, a true story is now considered that is reflective of the THM (at least for its time), which involves characters (two theoretical physicists) whose academic credentials and research portfolio were, and remain, second to none. This is to illustrate how the THM can make such an important impact on society, above and beyond the manifestations of the 'Ivory Tower'.

One of the most important icons of the Information Technology (IT) revolution we enjoy today was first established by Leo Szilard (e.g., [82,83]). This was a result of their solution to the 'Maxwell Demon' problem, a thought experiment leading to a paradox, named after James Clerk Maxwell, who unified the Physics of Electricity and Magnetism in the 1860s. Maxwell had originally proposed the thought experiment as a result of their work on the properties of ideal gases. He considered a model where gas particles are free to move inside a container and whose interactions occur through elastic collisions when they exchange heat with each other (energy and momentum being conserved). Some of these particles have low velocities, and others have higher velocities. The velocity profile of such particles was taken by Maxwell to conform to a Probability Distribution Function known as the Maxwell-Boltzmann Distribution, which has a well-defined maximum value-the 'mode' of the distribution. This is the velocity at which the majority of the gas particles move (the most probable velocity), and Maxwell showed that this velocity is related to the temperature of the gas where the most probable velocity is proportional to the square root of the temperature. The energy associated with this particle velocity (through Newton's famous energy equation) is equal to the product of the temperature and a constant of proportionality-the Boltzmann constant.

The thought experiment considers a 'Demon' operating a frictionless shutter that partitions the container into two sections. The shutter can be opened to allow particles with a velocity less than the most probable velocity to enter into one section of the container and particles with velocities greater than the most probable velocity to enter into the other section. Both the container and shutter are taken to be perfectly thermally isolated. In this way, high and low velocity gas particles are separated into the two sections of the container, preserving their velocities. Consequently, the equilibrium temperatures of the two sections become higher and lower than that of the original container.

For a classical thermodynamic process, work can only take place when there is a temperature gradient, and, for an irreversible process, the 'Entropy' (a measure of the disorder of a system) associated with that process always increases; the change in Entropy being given by the change in the work divided by the temperature. This is the basis for the second law of thermodynamics, a law that appears to be broken according to the thought experiment considered by Maxwell. This is because the Entropy of the two sections is now different, and, given that there is a decrease in temperature in one of the sections, the Entropy has been lowered without expending energy.

Leo Szilard was a classic example of eastern European Intelligentsia. Born and educated in Hungary, and, under the supervision of Albert Einstein at the University of Berlin, in their 1922 doctoral dissertation and a companion landmark paper [84], he showed how Maxwell's paradox can be solved by taking into account the fact that, in order for the Demon to open and close the shutter to let particles of different velocities through, a decision must be made. Furthermore, this decision is based on gathering information on the velocity of a particle a priori before it is let through the shutter or otherwise. The in- 
formation measure is taken to provide a balance to the apparent decrease in the physical Entropy, a measure that is therefore compounded in the so-called 'Information Entropy'. In this respect, Szilard's principal contribution was to consider that the Demon must be an intelligent being that can make a decision based on a priori information on the velocity of a particle. This is an obvious but critical issue, and one that Maxwell had failed to conceive of and include in his original thought experiment.

Szilard's original concept on Information Entropy has become a fundamental basis for digital information theory. He showed that there is always an increase in the Information Entropy for any and all measurements, a concept that was independently 'discovered' by the communications engineer and cryptographer Claude Shannon in 1949 (to whom credit is usually but erroneously given) [85]. In developing a solution to a paradox in thermodynamics, Szilard introduced an idea that is arguably the single most important icon of the information revolution today. This is because Information Entropy provides the key for estimating the (average) minimum number of bits needed to encode a string of symbols based on the frequency of those symbols. It, therefore, represents a fundamental criterion - a limit—as to how much information is communicable digitally in terms of a sequence or 'string' of bits. Further, Information Entropy is a fundamental measure that can be used to determine the intelligibility or otherwise of a binary string. This is important in the search for other intelligent beings through the reception and processing of radio signals, for example [86].

What has all this got to do with the THM? Just as it is not fully appreciated that it was Leo Szilard who first developed the iconic formula for the IT revolution that dictates the $\mathrm{ebb}$ and flow of our lives today, so it is not appreciated that the context for their work was not an Ivory Tower in Berlin but part of an industrial problem of the time-namely, how to design and manufacture a refrigerator that satisfied health and safety requirements.

In the 1920s, the principal chemical refrigerant was Ammonia, which was used in a single-cycle design for the operation of refrigerators. It had been reported at the time that in some cases, the Ammonia had leaked through the failure of a seel, leading to fatalities. This inspired Szilard and his doctoral supervisor, Albert Einstein, to investigate available technologies in order to design a refrigerator with no moving parts, thereby improving upon the safety of a refrigerator. Coupled with Szilard's understanding of thermodynamics and Einstein's in-depth knowledge of writing and submitting patents, they filed a number of patents relating to the design of the so-called 'Einstein Refrigerator' [87]. In the context of Szilard's solution to the Maxwell Demon problem, a refrigerator can be considered a thermally insulated container with a door. The door is then equivalent to the shutter between the two 'sections' considered in the 'Maxwell Demon' problem: a section that gets colder (the interior of the refrigerator) and the section that get hotter (the room in which the refrigerator is housed).

One of their aims was to develop a business to manufacture the next generation of refrigerators, which might have been a spin-off company from Berlin University. However, an important event intervened that prohibited this, namely the 'Wall Street Crash' of 1929, which rapidly led to an economic depression world-wide that was specifically detrimental to Germany. Thus, investors were not keen to invest in a start-up company of the type that Szilard and Einstein were considering, and the business venture failed before it had even started. Nevertheless, it was in the context of the industrial and practical problems that they were attempting to solve that Szilard's thought experiment led to a deeper understanding of thermodynamics, an understanding that now underpins the basic principles of all digital processors and digital communications.

The purpose of introducing this lesser-known event in the history of physics is as follows: If intellectual elites, such a Szilard and Einstein, whose contributions to science require no introduction, considered the importance of industry-based problems, then just who do lesser rank and file academics of today think they are when they distance themselves from getting involved in industry-based problems associated with private enterprise. Their preference to remain in an 'Ivory Tower' and maintain their insular 
comfort zones not only limits their horizons but exacerbates a tradition that is incompatible with institutes whose purpose should be to prepare the younger generations for the 'University of Life'.

It is interesting to note that Szilard is well known for many other contributions to Physics, most notably, his concept of a neutron-induced chain reaction to sustain nuclear fission. A patent on this idea was filed in 1933, granted in 1936 and assigned to the British Admiralty to ensure its security [88]. This was many years before the experimental verification of nuclear fission in December 1938 by physicists Lise Meitner, Otto Frisch, Otto Hahn and Fritz Strassman at the Kaiser Wilhelm Institute of Chemistry in Berlin, who were not aware of Szilard's contributions at the time. Moreover, it was Szilard who wrote the letter to president Roosevelt that initiated the Manhattan project, asking his previous supervisor to sign the document because of their greater international acclaim [89].

It is arguable that Szilard never rated their earlier work on thermodynamics as, from a psychological point view, he may have associated it with the failure of the business venture he was pioneering. In this respect, it is not a coincidence that their seminal paper entitled On the Decrease in Entropy of a Thermodynamic System by the Intervention of Intelligent Beings was published in 1929 [84]. However, their efforts to investigate a scientific and engineering problem that was of commercial importance led to this work becoming one of the most important in the history of Physics and the digital IT-dominated world we live in today. Furthermore, this is due to the juxtaposition of academic excellence and an industrial problem that lies at the heart of the THM. For this reason, it should be more fully respected by rank and file academics and learning providers who currently frequent the UK HE system. They must start to understand the changes that are going to be imposed upon them. These changes and the THM ethos is perhaps well expressed by Wernher von Braun when he stated that Pure research is what I do when I do not know what I'm doing. This is the subject of the section that now follows.

\section{Current Problems with UK HE}

The idea that through an endless stream of government White Papers, coupled with select committees, conferences, workshops and so on, will lead to universities coming to terms with the current challenges and changes that are so urgently required, let alone implementing them, is a strategy that is doomed to failure. Its only purpose is to maintain the status quo while giving the illusion of implementing a change of direction. This is something that many university vice chancellors and staff would welcome; not the changes that is, just the excuse to talk about them. Thus, what can and should be done and what strategy can be implemented to make things happen? To start with, we must understand the nature of the rot and why it has occurred. This is discussed in the following sections.

\subsection{From Grants to Tuition Fees}

In the 1960s, slightly over one in ten (approximately 12\%) of school leavers went to university in the UK. Sixties students did not require loans; their fees were paid in full by local educational authorities, and there was a means-tested annual grant of up to GBP 340 to cover living costs, thereby allowing students from deprived backgrounds to undertake a university education. Moreover, the remit of the degree that was awarded did not necessarily fix the nature of the career into which a graduate would embark. The university experience was perceived to be a mark of maturity and preparation for a career in a broad spectrum of activities, even if much of that experience had been infected by the values of the permissive society of the time.

In the 1970s, one in seven 18-year-olds (some 14\%) entered HE in 1972. However, this percentage fell over the decade as university funding was cut, and vice-chancellors refused to reduce the amount spent on each student. Consequently, many 16-year-olds school leavers opted not to go into the sixth form because there was no guarantee that after two years of A-level studies, a place could be found for them at university. Further, there was a reasonably healthy manufacturing base for such school leavers to enter an industry. 
By the end of the decade, the grant for students had increased from GBP 380 to GBP 1430 in 1980.

The 1980s produced a massive expansion in UK HE, masterminded by the Secretary for Education, Kenneth Baker. This was necessary because of the decrease in the jobs available for school leavers due to the systematic reduction in manufacturing industries and the transformation of the UK into a service industry. By 1990, one in five 18-year-olds were entering the HE sector, but the funding for each student started to be considerably reduced. In 1989, the government introduced a mortgage-style student loan scheme to compensate for any increase in the annual grant, although grants of up to GBP 2265 were made available for students from poorer families. Moreover, because the 'Cold War' came to an end in 1989 (with the fall of the Berlin Wall), the emphasis on Science, Technology, Engineering and Mathematics (STEM) to maintain the defence sector was perceived to be less important as funding for the Scientific Civil Service was massively reduced. Thus, school leavers were encouraged to undertake a university education, take out a loan and study for a degree in any subject as long as it helped reduce the youth unemployment rates of the time.

The 1990s witnessed another boom in UK HE with many of the Polytechnic's being given university status in the early part of the decade. In 1997, the new Labour government abolished the student grant, which was worth GBP 1710 and from 1998 introduced a new system involving a GBP 1000 means-tested and upfront tuition fee and low-cost incomecontingent loans. By 2002, 43\% of under-30's had experience of HE in the UK, and the Labour government of the time pledged to raise that to $50 \%$ by the end of the decade. Tuition fees became GBP 1100, offset by low-cost loans of up to GBP 3905.

In 2006, students became liable to pay up to GBP 3000 a year in fees paid after graduation, once they were earning GBP 15,000 a year. Repayments were made at a rate of $9 \%$ of income, with inflation-only interest payments.

In hindsight, one of the principal mistakes that was made in the early 1990s was the knock-on effect of the Polytechnics being given university status. There was nothing intrinsically wrong with this per se. What was wrong is that the new universities set about trying to copy the old universities instead of cultivating and improving upon what they were already good at and well respected for, namely technical training. Because of this, the gate was opened for companies to take advantage of what the new universities were quite literally throwing away.

The change in status of the Polytechnics included a drive for the new university sector to become research active. However, and most unfortunately, this has come at the expense of the high-quality technical educational once provided by the Polytechnics from which they were derived. This has been exacerbated by the monumental increase in bureaucracy that has constipated the operational directives that most academics have been subjected to as the student population has increased. It has led to an imbalance in the hierarchy of university structures in which the scholars have become servants of the 'Bean Counters', which has not been in the interests of the student population. The HE system has been reduced to a business enterprise culture that is dominated by staff who have become increasingly unaware of their customer's needs-something through which no state economy can thrive. An icon of the current status is compounded in the 'Mickey Mouse degree', which is introduced and discussed in the following section.

\subsection{Mickey Mouse Degrees}

The term 'Mickey Mouse Degree' was originally coined in 2003 by the then Minister for Education, Margaret Hodge, as part of a discussion paper on the expansion of HE. She referred to a Mickey Mouse degree course as one where the content is not as rigorous as one would expect, and where the degree itself does not have huge relevance in the labour market and ... simply stacking up numbers on Mickey Mouse courses is not acceptable [90]. However, it is not just Mickey Mouse degrees that have flourished in the UK since the late 1990s but the large number of Mickey Mouse universities that have emerged and are now responsible 
for awarding them. The principal subject matter of the Mickey Mouse degree is perceived to be the Liberal Arts and Humanities. For example, President Obama joined the ranks of many who suggested that the liberal arts disciplines do not lead to jobs [91] and that universities must focus on science, not 'useless' arts [92-94]. Science and engineering degrees have also suffered from the 'Mickey Mouse Syndrome' and have been dumbed down over the years, primarily because of the lack of mathematical literacy that school leavers have.

If students graduating with such degrees were on state grants, then it would not matter so much. However, graduates of such degrees now have to borrow increasingly large sums of money to be awarded them. Consequently, they end up in a scandalously high level of debt before they have even started employment, and, should they be lucky enough to obtain a job, it is usually one that is far from the remit of the degree(s) they have taken for which there is usually an insufficient job market anyway.

The term 'education, education, education' used on many occasions by Prime Minister Tony Blair and colleagues around the time when student fees underwent a quantum leap (i.e., the Teaching and High Education Act of 1998 [95]) should be applauded. However, the underlying reality is that the $50 \%$ participation in HE vision was adopted to reduce the projected level of unemployment of school leavers as a direct result of the disestablishment of the manufacturing industry under the government of Margaret Thatcher. In short, it appears that the post-baby-boomer generation have been sold a Pup, whose increasing deficits are an indirect source of payment for the pensions and state health that the baby boomers are now receiving and increasingly requiring, respectively. This situation is another example where the younger generation and, primarily, the working-classes end up paying the price for maintaining the comfort zones to which the older generations have become accustomed.

As the Spanish philosopher, George Santayana said: Those who do not learn from the past are condemned to repeat it [96]. However, there is an additional fundamental reality that needs to be understood, especially in relation to the vision of globalisation. This is that those who accept, use and pay for the technology of 'others' end up having to accept the influence and control of the 'others'. A recent example of this is the growth of the 5G communications infrastructure, courtesy of the Chinese telecommunications group Huawei. The head of MI6, Alex Younger, has been one of a number who have signalled security concerns over Huawei in regard to the development of 5G in the UK [97]. However, few appear to have questioned why this relatively new communications giant has taken a pole position so quickly in a technology that is fundamental to society and why the UK, for example, has not been able to compete. The fundamental reason for this is the correlation between information communication technology, data security and education. It is because Beijing have seen fit to educate their people properly in Science, Technology, Engineering and Mathematics (STEM), while London has had a relatively laissez faire attitude to allowing Mickey Mouse degree programs to proliferate. The disparity in promoting STEM by the central governments of the UK and China has led to an inequality in technical skills between the two countries. Furthermore, this has not gone unnoticed by those nation states who realise that it is now in their best future interests for the UK to carry on just the way it is, or at least, has been doing. In other words, used discretely, Mickey Mouse can be used as a powerful weapon, especially when he is encouraged to proliferate covertly throughout a nation state, given that he is not perceived by the status quo to be threat. This has been realised by an increasing number of overseas students, who no longer consider UK HE to be value for money and have reported this back to those who are often paying their exorbitant fees.

\subsection{On the Incompatibility of Linear Growth Models with Reality}

We are quite naturally and psychologically attuned to the idea, and indeed, the desire, for continued growth and prosperity in the future. This 'growth' is often perceived to have a linear progression in time where performance (which represents the growth in society, its industries and intuitions we relate our careers to, our contributions to them, 
our promotion prospects, financial rewards and so on) increases subject to the resources that are invested. Thus, as time increases, it is normal for us to perceive our roles within a 'system' whose performance is associated with greater prosperity. The rate of increase in this performance/productivity typically depends on incremental improvements that are driven by competitors. This leads to the generation of performance gaps that are filled through increased work under a controlling framework (central and local government) that is designed to maintain the long-term future direction of the system within the democratic traditions (or otherwise) of a given nation state [98] (Based on some of the ideas introduced by Professor Calie Pistorius during his seminar 'Bringing about a Step Change in the Organisational Renewal of Universities', at the University of KwaZulu-Natal, South Africa, 6 May 2016.).

The simplistic and naive description given above is entirely incompatible with reality, especially the realities associated with the growth of organic 'systems'. Whether the 'system' is a bacterial colony, a simple or complex animal or the behavioural dynamics of a group of animals, including human beings, its dynamic behaviour is usually governed by four fundamental phases. These phases are, in order of occurrence, the developmental phase, the growth phase, the saturation phase and the death phase. Given that the death phase is rarely fully completed (as it would lead to extinction), the cycle repeats itself. Each time this cycle occurs, mutations take place that promote the evolution of the system, conditioned according to the environmental circumstances that filter those mutations through which the cycle can grow 'stronger'. However, the time scales over which these cycles occur are very broad. This is why, when the time scales of the cycles are much larger than the average life time over which they can be observed, they are not always so easy to appreciate. Nevertheless, any dynamic behaviour that exhibits similarity over different time scales is an example of a self-similar process, and such processes are fundamental to the 'Fractal Geometry of Nature' [99] and systems thereof. Education systems are no exception.

Ignoring prior developments (and certain characteristics in regard to their continuity), the post-war HE system in the UK has undergone three of the four phases discussed above. The development phase started in the 1960s under a Labour Government when a range of Colleges of Arts and Technology throughout the UK were given university status. This included their development in terms of building infrastructure and the recruitment of staff, many of whom had an understandable allegiance to the socialist values of the time. Some of these 'Red-Brick' universities focused on science and technology and have secured excellent reputations. Other universities developed to sustain reputations in the arts and humanities, while others opted for a mixed portfolio determined by the traditions and continuity of the biases reflecting the characteristics of the Vice-Chancellors and the executive governance of the institutes.

In the early 1990s, the growth phase was initiated when, under a conservative government led by Prime Minister John Major, numerous Polytechnics and FE institutes were provided with university status. This was necessary in order to increase the university provision of a generation (the children of the baby boomers) that required a higher level of education than was previously needed. More importantly, it served to decrease the growing youth unemployment due to the severity of the financial rationalisations undertaken in the 1980s, which dramatically reduced those industries that had previously been able to offer school leavers employment and/or an apprenticeship. This is a process that continues to this day, and, in the space of some thirty years, the rate of growth in universities has been considerable. However, the nature and quality of the education that they now offer has become suspect, one that has been increasingly predicated on attending to the financial realities required to sustain their existence rather than attending to the welfare of their customers through relevant technical education. Furthermore, this is why the system has now entered its third phase, namely the saturation phase. Another less palatable word for this phase, but one that is perhaps a better description of the current reality, is ' stagnation'.

The current conditions have been brought about, not by the success of the HE system to stave off youth unemployment of the future but, its failure to adapt to the realities of that 
future. This is partly due to a lack of vision in that future, compounded in the technical and managerial inexperience, incompetence and unprecedented self-indulgence of university executives. However, there may also be a deeper reason for this, which is a natural reaction to the fall of the Berlin Wall in 1989, when a highly educated population developed to sustain the great socialist experiment were responsible for dismantling that experiment as a result of being so well educated. This is a correlation (i.e., the correlation between a quality education system and the effect it can have in forging changes that are not necessarily in the interests of the government that developed the system) that the western democracies would have observed and understandably compensated for, lest they also end up making the same 'mistake'. Whatever the principal reason for the age of stagnation in UK HE (and perhaps there is no one principal reason but a confluence of many), the ramifications and scandalous reality of the current situation is well served by the cartoon given in Figure 1.

So what can be done to rectify the problem expressed in Figure 1? The most important thing is to understand the nature of the strategy for change management in HE that is now required. This is discussed in the following section.

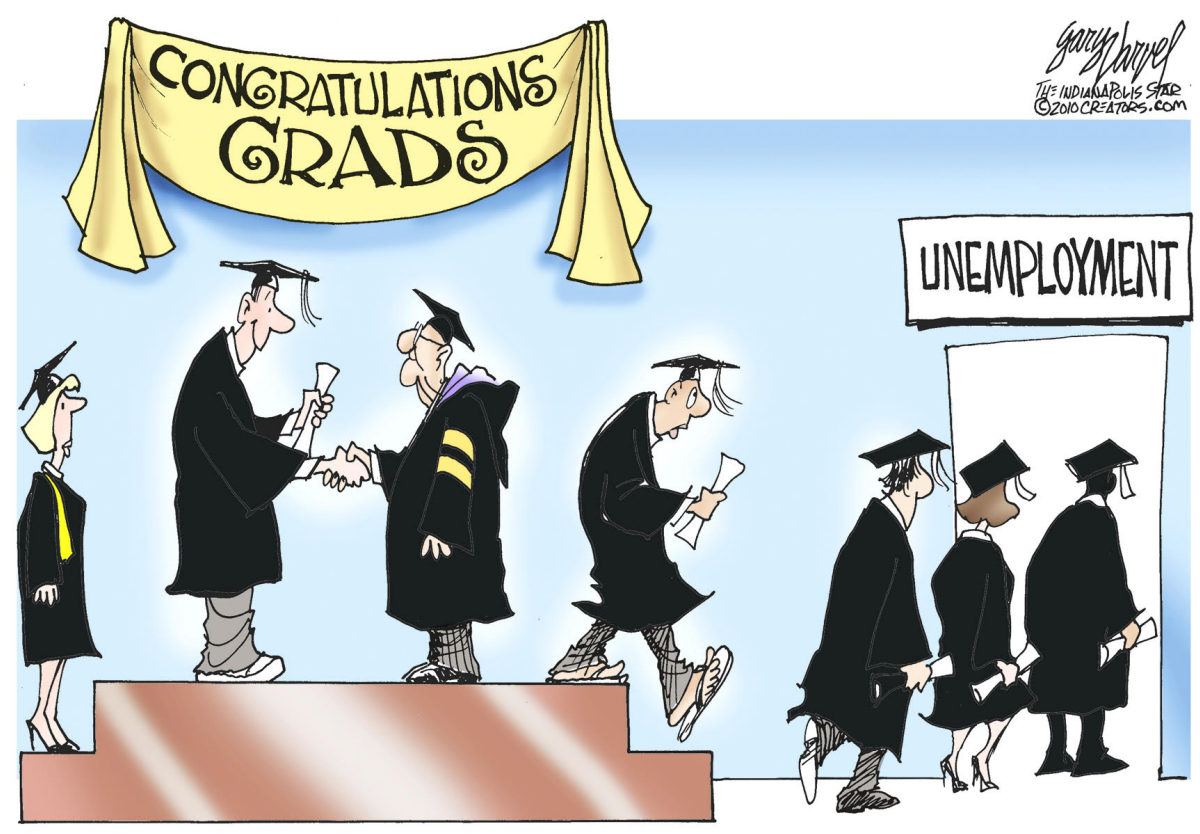

garyvarvel.com

Figure 1. 'Degree, Dole and Debt [100]. A cartoon [101] illustrating the 'flow' of UK graduates from a graduation ceremony to unemployment after having been burdened with an average debt of the order of GBP 50,000 in student fees, accommodation and other living costs, often for the privilege of being able to receive nothing more than a 'Mickey Mouse Degree'.

\section{Strategy for Change Management in Higher Education}

Organisational reviews have and continue to keep on being undertaken at all levels of management within HE, but few of them appear to be of fundamental significance and are understandably based on treading water while maintaining an eye on what might emerge from the current 'season of mists and mellow fruitfulness'. There are some basic issues that should be considered if such reviews are to be of any consequence. One of the most important is that knowledge knows no boundaries, whether it be physical, intellectual or digital. In this respect, the academic renewal that is so urgently required in UK universities that they must cater for an international mind-set, an organisational revival and the interdisciplinary virtues that necessarily reflects the reality of future generations and their working environment. Thus, the traditional and parochial 'Silo Mentality' must be outcast, competitive advantages developed and the drive for economies of scale realised. Examples of how this can be achieved include restructuring the academic enterprise by converting university faculties into multi-disciplinary schools instead of single-discipline depart- 
ments and establishing inter-disciplinary research institutes that cut across all faculties, for example.

What are the factors that are driving the organisational renewal that universities are faced with? A fundamental, and crucial factor, is the development of the virtual campus and distance learning. More and more competitors are emerging from organisations that are driving the agenda of distance learning, e.g., 'Arden University', the 'Online University Experts'. Not only are their degree courses consistent with the operating conditions of the working classes, but they endorse the concept of work-place-based learning and employability with significantly more experience and positivism than conventional universities.

Coupled with organisations, such as the City and Guilds London Institute, and others institutes that focus on industry-based apprenticeships, these universities are capable of introducing new interdisciplinary curricula and endorsing continuous change that transcends the traditional HE sectors. Furthermore, it is the 'products' (i.e., the graduates) of these new drivers in HE that employers are increasingly looking for. Above all, it is these initiatives that are helping to abolish Mickey Mouse degrees in Mickey Mouse disciplines from Mickey Mouse universities and driving the need to introduce a high-quality technical education in STEM. The issue is whether the current university sector is fit for a change where Twenty-first Century HE workers (not conventional academics) need to have:

(i) worked in and been successful in the respective industry;

(ii) regulated qualifications reflecting their training in teaching and learning;

(iii) obtained leadership and management training and qualifications thereof, especially at the executive level and not on the basis of having acquired a ten-a-penny MBA or attending a short course, especially if it has taken place at a university.

What is the strategy that is required for doing this? In order to address this issue, let us consider the following scenario. Suppose that a new appointment is made to the position of Minister of HE for the UK. Further, suppose that such a minister opted to make an unorthodox approach, whereby he or she embarked on regular fishing trips to see the vice-chancellor's and their executives on location in each university. One can imagine that in each case, they would be given the 'red-carpet treatment' and entertained with a range of excellent presentations and executive summaries where positivism was mandatory. This would be coupled with a wealth of statistical evidence quantifying developments in teaching practices, research, buildings infrastructure, quality control, the Centres of Excellence that have been created and so on. Even the finger sandwiches would be freshly prepared, no doubt in some Centre of Excellence for catering.

At the end of such events, it is usual for a ministerial visitor to provide feedback and to give an overview on the broad directions associated with a government manifesto on education, current White Papers and pending or current legislation. Suppose that, for each vice-chancellor and the assembled executive team, the minister was to read the riot act in regard to HE not providing what industries want and what the UK economy requires based on an evaluation from employers. The reaction from any vice-chancellor would quite naturally be defensive. This is understandable, and it is not entirely the fault of the executive of a university but rather the legacy of the staff they have to manage, whose experiences are often woefully incompatible with the way of the future.

It is of course all too easy to criticise the academic fraternity of UK universities. They have been subject to one initiative and policy change after another, relating to changes in strategy, as directed by Whitehall, but with little direct control from Whitehall, UK universities tend to be autonomous. This is a situation that is not replicated in continental Europe, where HE institutes are not conducted by a central government, but where university administrators are relatively few in comparison with the UK and fully understand that the 'few' are the servants to their academic masters.

By and large, UK university academics have tried hard to accommodate the change management that has been imposed from Whitehall. Perhaps they have not tried hard enough or not put up as much resistance as they might have, but that issue is now a technicality. Either way, with the sum total of the developments that have taken place, cou- 
pled with the economic realities of the past few decades, and compounded by the current COVID-19 Pandemic, the system has become akin to a brittle metal, whose malleability is at a minimum and is therefore destined to shatter. What then is the right strategy for change management that should now be adopted? This is discussed in the following section.

\section{The Solution in a Nutshell: A University Hopping Strategy}

While the conflict in Europe during the Second World War was well-defined geographically, the Pacific conflict was not. This is because after the pre-emptive attack on Pearl Harbour on 7 December 1941 by the forces of the Imperial Japanese Navy, the Japanese Army initiated an invasion of numerous countries in South East Asia in order to secure sources of oil and raw materials. By the end of 1942, in addition to their occupation of large regions of China and Manchuria, the Japanese Empire had expanded to include major industrial, economic and distribution centres, including Hong Kong, Singapore and the Philippines, for example. They had also occupied numerous Islands throughout the Pacific, many of which were not of any strategic significance in terms of the coming conflict with the USA. This situation and the realities of dealing with it were exploited in the strategy developed primarily by the Commander in Chief of the US Pacific Fleet, Admiral Chester Nimitz and General Douglas MacArthur in the Pacific War, 1943-1945, and was referred to as the 'Island-Hopping' or 'Leapfrogging' strategy [102].

The rationale for the Island-Hopping strategy was not to spend time, money and blood in taking back a complex of Pacific islands just because they contained a Japanese garrison. Instead, strategically important islands were targeted, in particular, those that could support a growing air force consisting of the new Boeing super-fortress under the supreme command of General Curtis LeMay. The purpose of this was to bomb Japan in to an oblivion until its government opted for unconditional surrender. This was achieved, the finale culminating in the use of the world's first nuclear weapons that devastated Hiroshima and Nagasaki in August 1945.

In regard to the Japanese forces that remained scattered throughout numerous pacific islands while the Island-Hopping strategy was being implemented, it was a question of letting them 'wilt on the vine'. In other words, the approach considered by the Americans was not to confront the problem everywhere but to go around the problem and focus on the key objectives that enabled dominance of the air to determine the outcome of the war. This has a clear and unambiguous synergy to the approach taken by Oliver Cromwell in the 1650s, as discussed earlier. Discontent with the academic traditions and institutes associated with English education at the time, he chose to establish brand new schools, academies and colleges that focused on technical training rather than non-technical conservatism, allowing many of the existing institutes to fade away organically. Furthermore, this is the strategy that is now being followed in the renewal of HE in the UK. It is based on starting with a clean slate by introducing and funding a new set of Technological Colleges that are characterised by the 'Solution in a Nutshell', as compounded in the following points:

(i) The new technological colleges, which in time will replace the rank and file universities, are administered by a small cohort of professionally trained managers, preferably those with an industrial, commercial and/or military background. Either way, such administrators must have significant experience in project and program management with appropriate vocational qualifications to match. In each case, a maximum three-year contract is provided, which is renewable upon completion, satisfactory performance and student evaluation. A primary object of such administrative staff is to minimise the administrative load(s) of teaching consultants and learning providers.

(ii) The new technological colleges have financial advisors and accountants with solid and proven experience in the management of funding for the sole benefit of college customers; all other investment portfolios being prohibited.

(iii) Conventional academic staff are replaced with industry consultants. The trainers that students come into contact with are respected experts in the field through their work with industry and, without exception, contracted to provide teaching on a per 
module basis. If the student evaluations are negative, then the module contract is not renewed. All trainers are, by default, expected to have undertaken a T3 (Train the Trainer) course and continuous T4 programs to introduce state-of-the-art teaching techniques and technologies.

(iv) Colleges focus on the National Vocational Qualification award scheme working with institutes, such as the City and Guilds, on developing opportunities for their students to enter earn-as-you learn schemes with local industries as apprentices in relevant technologies, ideally leading to the award of professional qualifications by relevant institutes.

(v) Research funding is only provided to specialist research institutes that are independent of a university or are centres for research excellence established within a university. Research contract overheads are set to a minimal level compatible with the infrastructure (physical and managerial) required. The projects are taken to be highly focused and the number reduced so that there is no proliferation of Mickey Mouse research grants in addition to Mickey Mouse qualifications across the sector. Research is also encouraged to take place elsewhere, not on the basis of securing government funding but on an individual philanthropic basis.

Examples in the realisation of points (i)-(v) above, which are taking place, are considered in the following section. For now, it is important to stress that this 'University Hopping Strategy' has a very positive function. It provides a solution to the 'Angry Dinosaurs Problem'. Having to explain the nature and effects of an approaching asteroid to the dinosaurs is just a waste of time. This is because they will not understand it, and even if they could, what can they really do about it? It is better to let nature take its course by virtue of customer (student) choice, especially once that choice has been established, e.g., [103-105].

For the universities that remain from the fallout to come, there is a further advantage that is related to the fast tracking of degree programs. For some time, many reputable UK universities have been recognising NVQs and introducing what are, in effect, fast track degrees, whereby a student with an appropriate NVQ can enrol on a one- or a two-year degree program in order to graduate with a Bachelors degree. This has the effect of reducing the fees that students have to pay to couple vocational qualifications to conventional degree programs and thereby integrate separate streams of qualifications relevant to the THM. There is also a positive knock-on effect for those universities that survive this reformation in English HE, which is that mainstream university academics will have significantly more time to undertake their research in an appropriate and multi-disciplinary research institute. This will also enable the 'Medici Effect' [106] to come to fruition when exciting things happen at the interfaces and intersections between different disciplines by exposing different fields of interest to one another and provide inter-disciplinary cross-pollination. In this regard, a problem-focused rather than a discipline-focused approach is required that can provide stimuli for academic renewal and act as a 'Silo-killer'.

\section{On the New Age of the Technological College}

In this section, two examples are considered that are representative of the new age of the Technological College that is evolving in the UK. They are illustrative of the realisation that a university degree is 'not the only route to success' and the recent announcement of plans to reform post-16 education in order to give employers the skilled work force that is needed [107], following the UK governments 2019 landmark review of HE [108].

In 2014, Microsoft identified the order of 100,000 technical, programming and ITrelated jobs in the UK that could not be filled for lack of appropriate skills of UK graduates. Consequently, and after significant irritation in regard the matter, in December 2014, Prime Minister David Cameron announced the establishment of the first new college of its type since 1993. The Ada National College for Digital Skills [6] opened its doors in September 2016 with the following mission statement: The mission of the College is to work with industry 
to design and deliver an institution that provides the education and support needed for all its students to progress into highly skilled, computing-related roles.

The focus of this college is to provide a broad portfolio of students (from school leavers to more mature students seeking a career change) with the hands-on skills required to enter the digital technologies job market. This is a very relevant example of the strategy discussed earlier and is a quintessential case study of history repeating itself when, under the leadership of Oliver Cromwell, the stagnant education system of the times was replaced by new schools, academies and colleges.

The learning providers that work with the National College for Digital Skills are not traditional academics but industry-based experts with a wealth of practical experience in digital technologies from basic computer programming skills to current advances in Artificial Intelligence, Robotics and Machine Learning, for example. It is an example of a new college that provides an essential contribution to filling the job roles of the future that are associated with the so-called 'Big-data Society'. The type of industries that relate to this society have and will continue to drive progress in the communications infrastructure of the UK, data management and security, financial management and trading using cryptocurrencies, new health care technologies and personalised medicine, renewable energy, and, given the current COVID-19 pandemic, biosecurity and public health management.

Another example of the new age of the technological college is the Institute of Digital Technology at Bletchley [109], which is part of the Milton Keynes College [110] and opened its doors in September 2021. The aim of the College is to once again focus on developing the hands-on programming and technical skills required by an industry where the industry works hand-in-hand with the Institute by designing the modules and their curricula, presenting the material and tutoring students who have gained apprenticeships through the earn-as-you-learn schemes. This is an example that reflects the UK governments drive to by-pass the traditional university sector in terms of focus and funding. In this case, the aim is to reflect the work undertaken at Bletchley Park during the Second World War when scientists and engineers developed the bed-rock of the IT revolution. This is because it was at Bletchley Park that the worlds very first (partially) programmable computer-the Colossus - was designed, built and operated.

The Colossus project was undertaken by the practically minded telecommunications engineer, namely Thomas Flowers and his team. Flowers was a post-office engineer working for the Post-Office Research Station and an expert in the design of the electromechanical switch gear required to operate the telephone exchanges of the time. It was because of this knowledge that he was in a position to build a machine that, then as now, is essentially composed of a large set of switches. Installed at Bletchley Park in June 1944 and reconstructed in the mid-1990s, the Colossus 'read' the encrypted information communicated by the German high-command from the Normandy landings on the 6 June 1944 until the end of the war in April 1945.

It is most appropriate to praise and recall the work of the Cambridge academic Alan Turing who was recently, through a public poll, accepted to be the face of the new GBP 50 note. Turing was a crucially important figure in the development of digital computing (at least, from a theoretical point of view) and single-handedly improved upon the Enigma decryption techniques originally developed in Poland during the 1930s. However, the aim of the Institute of Digital Technology at Bletchley is to produce graduates with the technical skills of Thomas Flowers and not just the theoretical ideas of Alan Turing. Such aims are not designed to necessarily inhibit individuals from contributing the incredible originality and long-term influences of Alan Turing, merely to provide the technical excellence required by a society that has evolved to become reliant on the legacies of both Alan Turing and Thomas Flowers and many other scientists and engineers besides.

Alan Turing obtained prestigious qualifications from Cambridge University. By comparison, Thomas Flowers had qualifications from the City and Guilds London Institute. The work undertaken at Bletchley Park during the Second World War is illustrative of the fact that both such qualifications are important and must be respected in equal measure, 
lest the distinctions between a university (Cambridge or otherwise) and the City and Guilds become distorted through a clash between reality and the class struggle.

In 2011, the author of this article published a book entitled 'Cryptography and Steganography' [111] through the Erasmus Mundus teaching programs being undertaking at the time in the Centre for Advanced Studies at the Warsaw University of Technology, Poland, who published the work in their 'Lecture Notes Series'. The material focused on the development of new algorithms and applications in data security and was aimed, then as now, at encouraging students to develop their own software to test out the algorithms being considered using a 'hands-on approach'. Upon returning to the UK, the work was passed on to a senior academic at a highly reputable UK university who was responsible for teaching Cryptography. The reaction to the material presented in the book was that it was 'far too practical' to be of relevance. In light of this statement, one might wonder whether if Station- $X$ at Bletchley Park had taken a similar attitude during the Second World War, this article might have been written in German!

\section{On the Impact of Information Technology on Education}

By considering Einstein's evolution equation for a Lévy distributed system, it can be shown that the Continuity Equation reduces to the Diffusion Equation subject to the Central Limit Theorem [112]. For a social system, this result can be interpreted as follows: Given sufficient time, the continuity of one idea will reduce to the diffusion of many ideas, providing a disruptive technology can be developed to 'open' the system and 'catalyse' the process. Further, once this reduction has matured, the diffusion of many ideas within the system will generate more and more disruptive concepts. The continuity of one idea is described by the Continuity Equation, which defines the conservation of mass or charge, for example. The Diffusion Equation (which governs the distribution of heat in a material over time, for example) describes the interaction and exchange of ideas between peoples from different backgrounds and cultures. The issue of providing 'sufficient time' (which is an ill-defined statement) relates to the governance of the Central Limit Theorem, where the linear aggregation of random systems (irrespective of their initial statistical distributions) tends to reduce to a system that is characterised by a normal distribution. The use of a Lévy distribution in regard to Einstein's evolution equation is consistent with the concept of introducing a disruptive technology to 'open the system' and initiate the process that takes place afterwards.

In 1439, a disruptive technology was conceived that had a huge influence on society. This was the printing press, which was developed in Mainz, Germany, by Johannes Gutenberg [113]. It played a key role in the development of the Renaissance and the scientific and engineering revolutions that followed. It was the basis for modern knowledge-based economies and the spread or diffusion of ideas into the mass populous. Thus, it was arguably the first technology of its type that may be identified with the concept of information distribution.

A consequence of the introduction of this disruptive technology was the dissemination of the disruptive concepts attributed to Martin Luther in Wittenburg from 1517, which catalysed the Protestant Reformation and the Age of Reason and Enlightenment [114]. Luther was a highly well-educated and prolific writer and had it not been possible to print his books, papers and pamphlets through the disruptive technology of his time, then his ideas might have remained closed to the populous. Although very limited compared to now, the fact that he could distribute his views throughout the German speaking peoples and beyond, led to developments in education and the broad spectrum of cultural activities that accompanied it. For example, Germany is considered, and rightly so, to have the longest continuous and uninterrupted tradition in the development of western music and to an extent that overshadows all other nation states. Why should this be? Because Martin Luther had written extensively on the importance of music in Christian worship, which was to be inclusive of the 'audience'. Thus, when Johannes Sebastian Bach wrote his contiguous stream of Cantatas along with a wealth of other music, he was doing more than earning 
a living. He was doing his master's bidding, a bidding that was expected within the cultural framework of his time. Bach's influence on musical form and its development is unprecedented in the history of western civilisation, but this is not what he had in mind at the time. In his mind, he was contributing to the Reformation; one that was made possible through the printing of his scores and in so doing, led to the development of musical notation in an attempt to minimise the costs associated with the printing techniques of the time. Thus, in more ways than one, the printing press provided the route through which Europeans were able to more fully appreciate the meaning of the phrase, 'Veni Creator Spiritus' (Come, Spirit of Creation).

In 1985, Michael Gorbachev became the eighth and last leader of the Soviet Union. He was the General Secretary of the Communist Part of the Soviet Union from 1985 to 1991. Upon coming to power, it is said that he told his wife that he was now in charge of the largest and best-educated country in the world and yet people could only talk about life in the kitchen. Actually, the kitchen is not a bad place to discuss life; second only to the pub and the bedroom but not necessarily in that order! Shortly after becoming leader of the best-educated country in the world, he introduced their policy of openness or 'Perestroika'. He also embarked on a policy of positive discrimination in which those who were not part of the old establishment were promoted to positions of prominence in all aspects of society. These policies were examples of disruptive concepts and led directly to the fall of the Berlin wall in 1989 and the collapse of communist systems the world over except in China. This is because by then, China was pursuing a route to enlightenment based on a principle introduced by Deng Xiaoping, namely it does not matter whether a cat is black or white, as long as it can catch a mouse [115] — preferably a mouse with more than a Mickey Mouse degree!

The collapse of the communist system in the USSR and the Warsaw pact was catalysed by Gorbachev's disruptive but necessary policies. However, they could not have been effective or influential if it had not been for the development of another disruptive technology, namely the early stages of those technologies associated with the Internet in the 1980s and the World Wide Web in the 1990s, which we now take for granted. In this sense, and, if a parallel can or should be made in respect of Gutenberg and Luther in the Sixteenth Century, then it is, respectively, Sir Timothy Berners-Lee and Michael Gorbachev in the Twentieth Century. The Internet aside, more conventional information technology was used to catalyse the coming changes for the communist block, such as the distribution of advanced printing facilities by the CIA into Poland in order to aid the development of the Solidarity movement during the 1980s; Poland being the very first communist domino to fall. Thus, the distribution of information using old, new or emerging information technologies is a critical source of disruption that has seeded and continues to disseminate disruptive concepts and a hunger for change. Furthermore, now that hunger is set to significantly change the modus operandi of $\mathrm{HE}$, an effect that has been understood for some time and will lead to a dim future for any and all universities that fail to accommodate [116].

In both cases, i.e., the introduction of the printing press in the 1520's and the creation and development of the WWW in the 1990s++, the technologies associated with the distribution of information to the populous has driven the radical changes that are reflected in the continuity of one idea transforming to the diffusion of many. It is possible that, in a broad societal context, this process is as natural in a social system as it is in a physical or biological system. Coupled to this possibility, however, is the inevitable resistance to change by the established authorities of the time, who fail to understand some of the basic laws of statistical physics and the dynamical process of all organic systems (including their own).

In the appalling scenes that took place in Washington on 6 January 2021 [117], one of the flags that was waved stated 'No more Bullshit'. While the behaviour of this form of support for President Trump was entirely reprehensible, the sentiment associated with this statement is not, irrespective of the individual who encouraged it. Unless this sentiment, and what it represents in the larger societal context, starts to be appreciated by current and future governance, the rift that has been initiated will continue to grow, especially in the 
younger generation who perceive that they are being used-they are, especially in regard to the educational provision they are being provided with.

It would appear that Donald Trump has opened a 'Pandora's Box'. In this respect, the educational fraternity that has seen fit to deprive emerging generations of a future that is commensurate with parental expectations, guidance and advice, has become responsible for its own demise; such is the reality of the flow of digital information that will continue to ensure that no one trusts anything and everyone questions everything. It is in this context, and that of the COVID-19 pandemic, that the next revolution will come into effect, a revolution concerning the effect of IT on education, a revolution that, like the age of enlightenment, will radically change society.

By way of an example, the author of this article has been involved in IT, Computer Science and, more latterly, Cryptography for over 30 years. A life-long Fellow of the British Computer Society, the author has developed a number of spin-off companies, all of which related to the author's research in areas such as Computer Vision and Artificial Intelligence. The knowledge gained to do this is not owed to any university or academic institute and their convoluted approach to managing computer centres, for example. Instead the author's knowledge of computer science is a direct result of the efforts of an entrepreneur who never bothered graduating from a university, namely, Lord Alan Sugar, whose business efforts provided the opportunity for the author to purchase a personal computer, an Amstrad 640, in 1988. This gave a level of independence that was devoid of interference from lecturers in computing, computer managers and the like and facilitated the chance to learn how to program a computer through practical experience using the relatively limited literature available at the time without being confused by self-serving academics. Consequently, it was Alan Sugar who did more for the author's education and professional development than any university did then or could do now.

This recollection highlights a current problem that has been exposed as a result of the COVID-19 Pandemic effect on education. This is the issue of 'Digital Poverty'. With the increasing focus in regard to online learning, Digital Poverty is set to limit the training and education of learners more fully than any other educational policy. Furthermore, the cost associated with solving this problem compared to the combined salaries of university academics is surely minimal. In short, having a personal computer and access to the internet can do more for the education and skill development of younger generations than any university. Thus, just as Alan Sugar provided the author and many others with an affordable facility to develop hands-on IT skills, so too should current and future governments do more for education by eliminating Digital Poverty than anything else.

\section{Concluding Remarks}

The current crisis in UK HE is compounded in what current employers of its graduates are constantly saying, namely that while the cost of education to both the state and students alike is growing, graduates are increasingly unprepared for the workplace. Thus, both parents and schools alike should therefore start to encourage school leavers to enter the 'University of Life' through earn-as-you-learn apprenticeships. This approach should be nurtured on the basis that:

(i) In the short term, more and more universities (at least those that remain in business) will offer fast track one- or two-year (maximum) degree programs that are predicated on an increasing recognition of and respect for an NVQ.

(ii) Such fast-track degree programs will be integrated into online learning schemes, especially in light of the fact that the COVID-19 Pandemic has forced the issue and shown that this mode of teaching is not only possible but desirable, especially in regard to cost effectiveness.

(iii) The current lack of parity of esteem between vocational and university educational pathways due to the class struggle will become dissipated.

It is point (iii) above that is the more difficult issue to resolve, as it represents a deeply embedded social reality in the UK, more so than in many other countries and societies. 
On the other hand, if the middle classes in the UK want to continue to do their children the disservice of limiting their future prosperity by being a sucker to educational values that have passed their sell-by date, then perhaps they should be encouraged to do so. This is because it will provide a new window of opportunity for the coming technically competent proletariat to influence the future prosperity of the state; something that Oliver Cromwell himself may have understood in his vision for the new English republic and perhaps, if he had lived long enough, might even have discretely encouraged.

After decades of rapid expansion in UK HE and the current period of stagnation that it is now experiencing, STEM has acquired a pole position in HE (world-wide). Nevertheless, the provision of STEM must start to focus on moving away from superficial learning to more in-depth training and become work-place-based and informed by industry experts. The growing number of new technological colleges are free to implement this approach as they are not constrained according to the contractual obligation of academic staff with tenured positions, whose mentality was moulded by a society of excess that no longer exists. This is why more and more state funding is set to be channelled into the development of the academies and technological colleges as it was in the 1650's to produce an educational wealth that was common to all the people of the Commonwealth and the 'New Jerusalem' they yearned for.

Even though the new technological colleges will have greater freedoms than the old and new university sector, their teaching and research programs must come to be based on continual developments in the curriculum and teaching practices that are based on the 'pursuit of practical knowledge' and the motto of the Massachusetts Institute of Technology, 'mind and hand'. Moreover, they must continually take into account that 'Shift Happens' in respect of the impact of IT on education and that for students starting a three-year degree, half of what they learned in the first year may be out dated by the time they have completed their studies [118]. On the other hand, this is a reality that will become null and void as the university sector starts to focus on fast-tracked final year degree programs predicated on a NVQ awarded by institutes, such as the City and Guilds London Institute, through the UK Academies [100,119] and the new Technological Colleges.

One of the reasons for the current need and inevitable future success of the new technological colleges is the knock-on effect of the UK Polytechnics being given university status in the 1990s. There was nothing intrinsically wrong with this. What was wrong is that the new universities set about trying to copy the old universities instead of cultivating and improving upon what they were already good at and well respected for, namely technical training. Because of this, the gate was opened for the private sector to take advantage of what the new universities were quite literally throwing away through disregarding their raison d'être.

Today, the situation is reversed, and UK universities, both old and new, are waking up to the fact that their degree programs are increasingly out of date and out of sync with current and future generations. When they are not trying to sell their Mickey Mouse degrees abroad, they are now attempting to cash in on the NVQ programs. Both approaches are symbolic of the HE system having been reduced to a business enterprise culture that is dominated by staff who have become increasingly unaware of their customers needssomething through which no state economy can thrive. Furthermore, until university academics are prepared to find a way to change accordingly, they will not be fit to manage the education of future generations. For the world is a very different place to that when many senior university academics were themselves educated, and the economic dominance of the free world is being challenged on all fronts. In order to develop further, that free world must rapidly engage in freeing future generations from a system that has created a populous that is dumb and in debt, thereby protecting itself from the implosion suffered by the old communist world as a direct result of providing its citizens with a free and comprehensive education in science and technology. The transitions that are going to take place should be understood in terms of a stark evolutionary fact, namely that it is not the 
strength in a tradition which matters, it is the ability for any and all traditions to be able adapt to the changing circumstances that forge the future which counts.

\section{Some Final Thoughts}

Given the change management that is required in HE, whether it be in the UK or elsewhere, is there another governing issue that is taking place throughout society, and, if so, how should education, in the broadest context of the word shape the future? The changes that took place in Europe from the Renaissance of the Sixteenth Century onwards have moulded society into the world order that currently exists. The word Renaissance means quite literally Re-birth; a re-birth of what? A re-birth, and, as of now, an all-out revival of the Greek view of life and Hellenistic culture. Hellenism is a culture that is arguably influencing current times in a more profound way than it did in the earlier part of the re-birth of Europe.

Hellenism is not only continuing to influence the future of society, it is actually accelerating society into that future. In this respect, the practices, traditions and all-out superstitions of the medieval mind have and continue to give way to the enlightenment of the ancient Greek and Roman civilisations. It is upon these civilisations that the underlying flow of modernity is based but not always accepted. This is due to the monotheistic cultures that emerged in Europe when Rome morphed from being a Pagan to a monotheistic society. In this respect, it may be surmised that the order of 1500 years went by when Greek philosophy lost out the monotheistic theology and for this reason alone, the post pagan Roman period before the Renaissance of the Sixteenth Century is deserving of the title, the 'Dark Ages'. For this was an age when people lived and died according to the whims and fancies of unelected heads of state, some of whom lost their heads!

Above and beyond developing a new class of technological colleges that focus on STEM, what should be the broader aim of education? What should, if any, be the ultimate goal? Surely, it should be something along the lines of constructing a society that gives opportunity to all in a way that harmonises their life-long quest for continued education and in doing so, yields a culture where judgement is based on, to paraphrase the words of Martin Luther King, the content of their character and not the colour of their skin. It is therefore worth noting that beyond the contributions and, in many cases, the inventions made by the ancient Greeks and Romans to Philosophy, Mathematics, Medicine, Politics, Music and Literature to mention just a few, the great virtues of their society were intrinsic multiculturalism and multi-theological tolerance. It was a society that was intrinsically devoid of any form of racism or sexism; the greatest empire of all—an empire of the mind.

In 1889, the great Russian writer, Anton Chekov, published one of their many essays and short stories for which he is now famous. It is entitled 'The Bet' [120], and it is an example of a time-honoured and quintessential Russian tradition in regard to asking but not necessarily solving the more important questions and issues of life. As such, this short story takes the reader on a fascinating journey in which the forced isolation and self-education of a young and idealistic lawyer leads to an evaluation of society that is far from that which he perceived before he became so well educated. Like many other Russian writers of the time, Chekov's rendition of how education can provide an individual with a level of freedom that transcends the trappings of a society with an out-dated modus operandi reflected a vision for the future that he could not have imagined but was nevertheless catalysed throughout their country in 1917.

The Russian revolution, its causes and its long-term effects have been studied and commented on by historians for decades. However, there is one thing about it that is undisputed. This is that it had the effect of draining the 'Petrograd Swamp', inclusive of changing the name of the city (which had originally been built on a swamp anyway). Furthermore, in doing so, it provided the potential for countless illiterate individuals to contribute their scientific, engineering, artistic and humanitarian talents to a new society. One such individual was Michael Gorbachev who managed that society through its final phase transition-from the saturation phase and time of stagnation through to the death 
phase. That this society, like any other, underwent its initial, interim and final phase transitions is not important, but the manner in which the death transition occurred is. Under the governance of a lesser well-educated and well-balanced individual, this paper might not have materialised, and, even if it had, there might be few people, if any, able or interested in reading it. This conclusion is something that the UK might do well to contemplate in regard to the phase transition that it is now entering; a transition that, above and beyond the education system it has conceived for its people, is going to become increasingly dependent upon a radical change in that system.

Funding: The research reported in this article has been partly and indirectly funded through the 'Bacon2020 project', by the Institute of Physics.

Institutional Review Board Statement: Not Applicable.

Informed Consent Statement: Not Applicable.

Data Availability Statement: The data used in this publication is all open source data.

Acknowledgments: The number of academic colleagues in the UK and beyond that the author has debated with over many years in regard to the remit of this work are too numerous to list. Instead, the author would like to acknowledge a late colleague-Derek Randall-who fell victim to the COVID-19 Pandemic in 2020 and, through their work with the author, helped to develop numerous apprenticeship and work-place-based learning programs in the early 2000s. No learning provider could have cared more for their customers than Derek Randall. He provided many hundreds of young school leavers, most of whom came from deprived backgrounds, with the opportunity to enter the workplace and develop their careers to a level of success that they might otherwise have not achieved. In respect of this, it is to the memory of Derek Randall that this work is dedicated, in the certain knowledge that he would have been a strong advocate of the problems that have been discussed and some of the solutions that have been considered.

Conflicts of Interest: The author declares no conflict of interest.

\section{References}

1. Byrne, E.; Clarke, C. The University Challenge: Changing Universities in a Changing World; Pearson Eduction Limited: Harlow, UK, 2020; ISBN 978-1-292-27651-9.

2. Remenyi, D.; Grant, K.A. (Eds.) University of the Future-Responding to COVID-19; ACIL: Melbourne, Australia, 2020; ISBN 978-1912764-65-5.

3. Muller-Heyndyk, R. Employers Think Graduates are Unprepared for the Workplace. HR Magazine, 17 December 2019. Available online: https://www.hrmagazine.co.uk/article-details/employers-think-graduates-are-unprepared-for-the-workplace (accessed on 20 January 2021).

4. Goodhart, D. Why Universities Are Not Fit for Purpose; AGF Tutoring. 2020. Available online: https://www.agftutoring.com/ why-universities-arent-fit-for-purpose (accessed on 2 February 2021).

5. Tatlow, P.; Boffy, R. An Educational System Not Fit for Purpose. The Guardian: Education Letters, 19 August 2018. Available online: https:/ / www.theguardian.com/education/2018/aug/19/an-educational-system-not-fit-for-purpose (accessed on 18 September 2020).

6. Ada National College for Digital Skills. Available online: https://www.ada.ac.uk (accessed on 12 December 2020).

7. Department for Business, Innovation and Skills. Higher Education: Success as a Knowledge Economy-White Paper. GOV.UK. 2016. Available online: https://www.gov.uk/government/publications/higher-education-success-as-a-knowledge-economywhite-paper (accessed on 18 March 2021).

8. Teaching Excellence and Student Outcomes Framework. Available online: https://en.wikipedia.org/wiki/Teaching_Excellence_ Framework\#cite_note-7 (accessed on 19 March 2020).

9. Walshok, M.L. Knowledge Without Boundaries: What America's Research Universities Can Do for the Economy, the Workplace, and the Community; Jossey-Bass: Harlow, UK, 1995; ISBN 0787900869.

10. Chambre, H.; Mclellan, D.T. Marxism. In Encyclopedai Britannica; Encyclopædia Britannica, Inc.: Edinburgh, UK, 2020. Available online: https:/ / www.britannica.com/topic/Marxism/Class-struggle (accessed on 7 February 2021).

11. Bacon, F. The Essays; Goodreads: San Francisco, CA, USA, 2020. Available online: https://www.goodreads.com/quotes/28623read-not-to-contradict-and-confute-nor-to-believe-and (accessed on 12 February 2021).

12. BrainyQuote: Bertrand Russell Quotes. Available online: https://www.brainyquote.com/quotes/bertrand_russell_141826 (accessed on 19 February 2021).

13. Morehead, C. Bertrand Russell: A Life; Viking Adult: New York, NY, USA, 1993; ISBN-10: 067085008X.

14. Boswell, J. Life of Samuel Johnson; Oxford University Press: Oxford, UK, 1970; ISBN-10: 0192810715. 
15. Germany: Apprenticeships to Boost the Workforce. BBC News, 10 February 2016. Available online: https://www.bbc.co.uk/ news/av/business-35532713 (accessed on 19 November 2020).

16. Department for Business, Innovation and Skills. Apprenticeships: Vision for 2020; GOV.UK. 2015. Available online: https: //www.gov.uk/government/publications/apprenticeships-in-england-vision-for-2020 (accessed on 7 January 2021).

17. Wikiquote: Oliver Cromwell. Available online: https:/ / en.wikiquote.org/wiki/Oliver_Cromwell (accessed on 23 February 2021).

18. Fraser, A. Cromwell: Our Chief Man; Orion: London, UK, 2001; ISBN-10: 9780753813317.

19. Idola Specus. Available online: https://en.wikipedia.org/wiki/Idola_specus (accessed on 14 February 2021).

20. Bacon, F. Novum Organum; Open Court Publishing Co.: Chicago, IL, USA, 1994; ISBN-10: 0812692454.

21. Galileo, G. Dialogue Concerning the Two Chief World Systems; Gould, S.J., Ed.; Modern Library Inc.: New York, NY, USA, 2001; ISBN-10: 037575766X.

22. Swart, K.W. Miracle of the Dutch Republic; Diana Muir Applebaum. 2012. Available online: http://www.dianamuirappelbaum. $\mathrm{com} /$ ? $\mathrm{p}=583 \#$.YABoUej7Rdg (accessed on 6 December 2020).

23. Van Gelderen, M. The Political Thought of the Dutch Revolt 1555-1590; Cambridge University Press: Cambridge, UK, 2002; ISBN 0-521-89163-9.

24. Harris, L.E. Vermuyden and the Fens; Clever-Hume Press: London, UK, 1953.

25. Darby, H. The Draining of the Fens; Cambridge University Press: Cambridge, UK, 1956.

26. Newton, I. The Principia: The Authoritative Translation: Mathematical Principles of Natural Philosophy; University of California Press: Berkeley, CA, USA, 2016; ISBN-10: 0520290747.

27. Dickensl, A.G. The English Reformation; Pennsylvania State University Press: University Park, PA, USA, 1989; ISBN-10: 0271028688.

28. Marshall, P. Heretics and Believers: A History of the English Reformation; Yale University Press: New Haven, CT, USA, 2018; ISBN-10: 0300234589.

29. Purkiss, D. The English Civil War: A People's History, 2007th ed.; Perennial: London, UK, 2007; ISBN-10: 0007150628.

30. Lipscombe, N. The English Civil War: An Atlas and Concise History of the Wars of the Three Kingdoms 1639-1651; Osprey Publishing: Oxford, UK, 2020; ISBN-10: 1472829727.

31. Hill, C. God's Englishman: Oliver Cromwell and the English Revolution; Penguin: London, UK, 2019; ISBN-10: 0141990090.

32. Firth, C.H. Oliver Cromwell and the Rule of the Puritans in England. Project Gutenberg.e-Book Number: 57268. 2018. Available online: https: / / www.gutenberg.org/ebooks/57268 (accessed on 22 August 2021).

33. Ross, E. A Biography of Oliver Cromwell. Endymion Press: 2018. ISBN 9781531292638. Available online: https: //www.amazon.com/Biography-Oliver-Cromwell-Estelle-Ross-ebook/dp/B07B4JVJVHhttps://books.google.co.jp/books / about/A_Biography_of_Oliver_Cromwell.html?id=hHtQDwAAQBAJ\&redir_esc=y (accessed on 22 August 2021).

34. Little, P. Oliver Cromwell: New Perspectives; Palgrave: London, UK, 2008; ISBN-10: 0230574211.

35. Royle, T. Civil War: The Wars of the Three Kingdoms 1638-1660; Abacus: London, UK, 2005; ISBN 978-0-349-11564-1.

36. Worden, B. The Rump Parliament 1648-1653; Cambridge University Press: Cambridge, UK, 1974; ISBN 978-0-521-29213-9.

37. Fraser, A. King Charles II; Weidenfeld and Nicholson: London, UK, 2002; ISBN-10: 075381403X.

38. Gillard, D. Education in England: A History (Chapter 3). Available online: http://www.educationengland.org.uk/history/ (accessed on 5 November 2020).

39. Dawson, J. John Knox; Yale University Press: London, UK, 2015; ISBN 9780300114737.

40. Quakers: The Quiet Revolutionaries 1. Available online: https://www.pbsamerica.co.uk/series/quakers-the-quietrevolutionaries/ (accessed on 12 December 2020).

41. Dandelion, P. The Quakers; Oxford University Press: Oxford, UK, 2008; ISBN-10: 0199206791.

42. Bright, W. A History of the Church from the Edict of Milan, A.D. 313, to the Council of Chalcedon, A.D. 451; Nabu Press: Charleston, SC, USA, 2010; ISBN-10: 1176403249.

43. Murphy, D. Cromwell in Ireland: A History of Cromwell's Irish Campaign; Orchard Press: Swindon, UK, 2010; ISBN-10: 1446019918.

44. Morden, P. John Bunyan: The People's Pilgrim; Illustrated edition; Cwr: Surrey, UK, 2013; ISBN-10: 1853458368.

45. Bunyan, J. The Pilgrim's Progress; Oxford University Press: Oxford, UK, 1975; ISBN 0198118023.

46. Resettlement of the Jews in England. Available online: https://en.wikipedia.org/wiki/Resettlement_of_the_Jews_in_England (accessed on 23 February 2021).

47. Gow, A.C.; Fradkin, J. Protestantism and Non-Christian Religions. In The Oxford Handbook of The Protestant Reformations; Rublack, E., Ed.; Oxford University Press: Oxford, UK, 2016; pp. 274-300. Available online: https://books.google.co.uk/books? $\mathrm{id}=7$ QiTDQAAQBAJ\&pg=PA296\# $\mathrm{v}=$ onepage\& $\mathrm{q} \& \mathrm{f}=$ false (accessed on 25 February 2021).

48. Edelman, T.M. The Jews of Britain, 1656 to 2000; University of California Press, Berkeley: CA, USA, 2002 ; ISBN 9780520935662.

49. The Works of Francis Bacon (1884) Volume 1. Available online: https://en.wikisource.org/wiki/Page:The_Works_of_Francis_ Bacon_(1884)_Volume_1.djvu/137 (accessed on 4 October 2020).

50. Bacon, F. The Wisdom of the Ancients. Available online: https://en.wikisource.org/wiki/The_Wisdom_of_the_Ancients (accessed on 4 October 2020).

51. Euclid. The Elements: Books I-XIII (Complete and Unabridged, Translated by Sir Thomas Heath); Barnes \& Noble: New York, NY, USA, 2006; ISBN 0-7607-6312-7.

52. Bronowski, J. The Ascent of Man (Illustrated Edition); BBC Books: London, UK, 2011; ISBN-10: 1849901155. 
53. Hartwell, R.M. Causes of the Industrial Revolution in England; New Edition; Methuen Young Books: North Yorkshire, UK, 1967; ISBN-10: 0416480004.

54. Smith, A. The Wealth of Nations; Digireads.com; Reprint Edition (30 March 2004). 2017. Available online: https://www. earlymoderntexts.com/assets/pdfs/smith1776_1.pdf (accessed on 9 February 2021).

55. Ivanenko, N. Education in Eastern Europe and Eurasia. Bloomsbury Academic, 2014; Available online: https://www.bloomsbury. com/uk/education-in-eastern-europe-and-eurasia-9781623561291/ (accessed on 9 February 2021).

56. Pergamon Press. Available online: https://en.wikipedia.org/wiki/Pergamon_Press (accessed on 9 November 2020).

57. The Biggest Scandal in Science: The Price of Knowledge. Available online: https:/ /www.youtube.com/watch?v=PriwCi6SzLo (accessed on 12 March 2021).

58. Marsh, S. Cheating at UK's TOP Universities Soars by 40\%. 2018. Available online: https://www.theguardian.com/education/ 2018/apr/29/cheating-at-top-uk-universities-soars-by-30-per-cent (accessed on 17 March 2021).

59. Parry, G.; Houghton, D. Plagiarism in UK Universities. Educ. Law 1996, 8, 201-215. Available online: https:/ / www.tandfonline. com/doi/abs/10.1080/0953996960080303?journalCode=cetl20 (accessed on 27 February 2021). [CrossRef]

60. Perkins, M.; Gezgin, U.B.; Roe, J. Reducing plagiarism through academic misconduct education. Int. J. Educ. Integr. 2020, 16, 1-15. [CrossRef]

61. Al-Akaidi, M. Fractal Speech Processing; Cambridge University Press: Cambridge, UK, 2004. Available online: https://drive. google.com/file/d/1qCgJkLs8EMwssVSj0p5RwzayPGlfUzRG/view?usp=sharing (accessed on 19 February 2021).

62. MDPI—Publisher of Open Access Journals. Available online: https://www.mdpi.com/ (accessed on 22 March 2021).

63. At UKZN a First for Africa, N.L.S. Available online: https://ndabaonline.ukzn.ac.za/UkzndabaStory/Vol3-Issue54/New\%20 Library\%20System\%20at\%20UKZN\%20a\%20First\%20for\%20Africa/ (accessed on 16 January 2021).

64. Chambers, J.D. The Workshop of the World: British Economic History from 1820 to 1880; Oxford University Press: Oxford, UK, 1968; ISBN-10: 0198880324.

65. Crease, R.P. The Workshop of the World: What Ten Thinkers Can Teach Us About Science and Authority (Illustrated Edition); W. W. Norton and Company: New York, NY, USA, 2019; ISBN-10: 0393292436.

66. Musson, A.E. The Great Depression in Britain, 1873-1896: A Reappraisals. J. Econ. Hist. 1959, 19, 199-228. [CrossRef]

67. Keegan, J. The American Civil War; Vintage: New York, NY, USA, 2010; ISBN-10: 0712616101.

68. Taylor, A.J.P. Bismarck: The Man and the Statesman; Hamish Hamilton Ltd.: London, UK, 1955; ISBN-10: 0241900603

69. Palmer, A. The Kaiser: Warlord of the Second Reich; Littlehampton Book Services Ltd.: Worthing, UK, 1978; ISBN-10: 0297773933.

70. State Socialism (Germany). Available online: https://en.wikipedia.org/wiki/State_Socialism_(Germany) (accessed on 14 December 2020).

71. Beveridge Report. Available online: https://en.wikipedia.org/wiki/Beveridge_Report (accessed on 14 December 2020).

72. What's the MIT Motto? Available online: https://mitadmissions.org/help/faq/motto-mens-et-manus (accessed on 23 March 2021).

73. Imperial Quits University of London. Available online: https://www.theguardian.com/education/2005/dec/09 /highereducation.administration (accessed on 23 March 2021).

74. Gay, H. History of Imperial College London, 1907-2007. The: Higher Education and Research in Science, Technology and Medicine; Imperial College Press: London, UK, 2007; ISBN-10: 1860947093.

75. Harold Wilson's 'White Heat' Speech Was Aimed at the 'Squeezed Middle'. Available online: https://www.theguardian.com/ science/political-science/2013/sep/20/harold-wilson-white-heat-speech (accessed on 24 March 2021).

76. This Be The Verse. Available online: https://www.poetryfoundation.org/poems/48419/this-be-the-verse (accessed on 28 February 2021).

77. The People's University. Available online: https://tribunemag.co.uk/2019/01/the-peoples-university (accessed on 27 February 2021).

78. What Is an NVQ? (National Vocational Qualification). Available online: https://www.vocationaltraining.org.uk/nvq-overview (accessed on 26 December 2020).

79. Young, M. National Vocational Qualifications in the United Kingdom: Their origins and legacy. In Advancing Social Justice, Promoting Decent Work; International Label Organisation: Geneva, Switzerland, 2010. Available online: http://www.ilo.org/ skills/projects/WCMS_145934/lang--en/index.htm (accessed on 27 December 2020).

80. Skills Training UK. Available online: https:/ / www.skillstraininguk.com/apprenticeships-1 (accessed on 7 November 2020).

81. Etzkowitz, H.; Zhou, C. The Triple Helix: University-Industry-Government Innovation and Entrepreneurship; Routledge: London, UK, 2017; ISBN 9781138659490.

82. Leo Szilard. Available online: http:/ / www.dannen.com/szilard.html (accessed on 5 Janurary 2021).

83. Szilard, L.; Weiss-Szilard, G. Leo Szilard: His Version of the Facts—Selected Recollections and Correspondence; The MIT Press: Cambridge, MA, USA, 1978; ISBN 0-262-69070-50.

84. Szilard, L. On the Decrease of Entropy in a Thermodynamics System by the Intervention of Intelligent Beings. Z. Phys. 1929, 53, 840-856. Available online: https://library.ucsd.edu/dc/object/bb2049336j (accessed on 22 August 2021) [CrossRef]

85. Shanon, C.E. A Mathematical Theory of Communication. Bell Syst. Tech. J. 1948, 27, 379-423. Available online: https: // people.math.harvard.edu/ ctm/home/text/others/shannon/entropy/entropy.pdf (accessed on 22 August 2021) [CrossRef]

86. Blackledge, J.M. On the Chirp Function, the Chirplet Transform and the Optimal Communication of Information. IAENG Int. J. Appl. Math. 2020, 50, 285-319. Available online: https://arrow.tudublin.ie/engscheleart2/218/ (accessed on 2 April 2021).

87. Einstein's Fridge. Available online: https://www.bbc.co.uk/programmes/b06z2x0j (accessed on 24 February 2021). 
88. Szilard, L. Improvements in or relating to the transmutation of chemical elements. In Provisional Specification: UK Patents and Design Acts 1907 to 1932; British Patent Office: London, UK, 1934. Available online: https://library.ucsd.edu/dc/object/bb90801 175/_1.pdf (accessed on 24 February 2021).

89. Einstein's Letter to President Roosevelt-1939. Available online: https://www.atomicarchive.com/resources/documents/ beginnings/einstein.html (accessed on 5 Janurary 2021).

90. Mickey Mouse Degrees. Available online: https:/ / en.wikipedia.org/wiki/Mickey_Mouse_degreesj (accessed on 6 Janurary 2021).

91. Jaschik, S. Obama vs. Art History. Teaching and Learning. 31 January 2014. Available online: https://www.insidehighered.com/ news /2014/01/31/obama-becomes-latest-politician-criticize-liberal-arts-discipline (accessed on 5 Janurary 2021).

92. Universities Must Focus on Science, Not Useless Arts. Available online: http://www.universityworldnews.com/article.php? story $=20140918151012537$ (accessed on 24 December 2020).

93. The War Against Humanities at Britain's Universities. Available online: https://www.theguardian.com/education/2015/mar/ 29/war-against-humanities-at-britains-universities (accessed on 25 December 2020).

94. Japan's Humanities Chop Sends Shivers Down Academic Spines. Available online: https://www.theguardian.com/higher-educationnetwork/2015/sep/25/japans-humanities-chop-sends-shivers-down-academic-spines (accessed on 26 December 2020).

95. Teaching and Higher Education Act. 1998. Available online: https://www.legislation.gov.uk/ukpga/1998/30/contents (accessed on 26 December 2020).

96. Santayana, G. George Santayana Quotes. 2020. Available online: https://www.brainyquote.com/authors/george-santayanaquotes (accessed on 7 March 2021).

97. Of MI6 Warns of Huawei Security Concerns, H. Available online: https://www.irishtimes.com/business/technology/head-ofmi6-warns-of-huawei-security-concerns-1.3718917 (accessed on 7 April 2021).

98. Psitorius, C. Bringing about a Step Change in Organisational Renewal in Universities. 2016. Available online: https://ukzn.ac.za/ukznnotice/seminar-on-bringing-about-a-step-change-in-organisational-renewal-in-universities / (accessed on 8 April 2021).

99. Mandelbrot, B. The Fractal Geometry of Nature; W. H. Freeman and Co.: New York, NY, USA, 1982; ISBN 0-7167-1186-9.

100. The Know List Academies: Academies Forum, Peter Dunne, 5 April 2012. Available online: https://www.youtube.com/watch? $\mathrm{v}=\mathrm{vtTonOUIAcI}$ (accessed on 6 June 2020).

101. Gary Varvel's Editorial Cartoons, Published 2010-05-10 (Image 47236). Available online: https: / /www.cartoonistgroup.com/ cartoon/Gary+Varvel\%27s+Editorial+Cartoons/2010-05-10/47326 (accessed on 22 August 2021).

102. Leapfrogging (Strategy). Available online: https://en.wikipedia.org/wiki/Leapfrogging_(strategy) (accessed on 23 March 2021).

103. Business Innovation Magazine, September. Government Announces Major Expansion of Post-18 Education and Training. 2020. Available online: https://www.businessinnovationmag.co.uk/government-announces-major-expansion-of-post-18-educationand-training (accessed on 4 February 2021).

104. Major Overhaul of Higher Technical Education Announced; Education, Training and Skills. 2020. Available online: https: //www.gov.uk/government/news/major-overhaul-of-higher-technical-education-announced (accessed on 6 Janurary 2021).

105. Updates, E.T. Major Expansion of POST-18 Education and Training to Level Up and Prepare Workers for Post-COVID Economy; fenews.co.uk. September 2020. Available online: https:/ /www.fenews.co.uk/press-releases/217-resources/55706 (accessed on 6 October 2020).

106. Johansson, F. The Medici Effect: What You Can Learn from Elephants and Epidemics; (First Trade Paper Edition); Harvard Business Review Press: Brighton, MA, USA, 2006; ISBN-10: 9781422102824.

107. Barnes, O; Sellgren, K. University Tuition Fees Frozen at $£ 9,250$ for a Year. BBC News: Family and Education, 21 January 2019. Available online: https:/ / www.bbc.co.uk/news/education-55735178 (accessed on 6 February 2021).

108. Coughlan, S. University Tuition Fees 'Should be Cut to $£ 7,500$ ’. BBC News: Family and Education, 30 May 2019. Available online: https: / / www.bbc.co.uk/news/education-48451474 (accessed on 12 December 2020).

109. Institute of Digital Technology. Available online: https: / / www.southcentraliot.ac.uk/ (accessed on 25 June 2021).

110. Milton Keynes College. Available online: https:/ / mkcollege.ac.uk/ (accessed on 26 June 2021).

111. Blackledge, J.M. Cryptography and Steganography: New Algorithms and Applications; Centre for Advanced Studies Textbooks, Warsaw University of Technology: Warszawa, Poland, 2011; ISBN 978-83-61993-05-6. Available online: https: / arrow.tudublin. ie/engscheleart2/40 (accessed on 26 August 2020).

112. Blackledge, J.M.; Kearney, D.; Lamphiere, M.; Rani, R.; Walsh, P. Econophysics and fractional calculus:Einstein's evolution equation, the Fractal Market Hypothesis, trend analysis and future price prediction. Mathematics 2019, 7, 1057. Available online: https:/ / arrow.tudublin.ie/engscheleart2/200/ (accessed on 2 November 2020). [CrossRef]

113. Kapr, A. Johann Gutenberg: The Man and His Invention; : Oxford, UK, 1996; ISBN-10: 1859281141.

114. Berlin, I. The Age of Enlightenment; Oxford University Press: Oxford, UK, 1979; ISBN-10: 0192830201.

115. Simpson, J.; Speake, J. The Oxford Dictionary of Proverbs; Oxford University Press: Oxford, UK, 2009; ISBN 9780191727740.

116. Noam, E.M. Electronics and the Dim Future of the University. Science 1995, 270, 247-249. [CrossRef]

117. 2021 United States Capitol Attack. Available online: https:/ / en.wikipedia.org/wiki/2021_United_States_Capitol_attack accessed on 26 August 2020).

118. Did You Know (Shift Happens). Available online: https:/ /www.youtube.com/watch?v=u06BXgWbGvA (accessed on 13 March 2021).

119. The Know List Academies: Academies Forum, Jonathan Blackledge, 5 April 2012. Available online: https://www.youtube.com/ watch?v=LwOJ3Rd_IjI (accessed on 6 June 2020). 
120. Chekov, A. The Bet (Short Story). Available online: https://en.wikipedia.org/wiki/The_Bet_(short_story) (accessed on 9 April 2021). 